William \& Mary Law School

William \& Mary Law School Scholarship Repository

$12-2020$

\title{
Punishing Pill Mill Doctors: Sentencing Disparities in the Opioid Epidemic
}

Adam M. Gershowitz

William \& Mary Law School, amgershowitz@wm.edu

Follow this and additional works at: https://scholarship.law.wm.edu/facpubs

Part of the Criminal Procedure Commons

\section{Repository Citation}

Gershowitz, Adam M., "Punishing Pill Mill Doctors: Sentencing Disparities in the Opioid Epidemic" (2020). Faculty Publications. 2015.

https://scholarship.law.wm.edu/facpubs/2015

Copyright c 2020 by the authors. This article is brought to you by the William \& Mary Law School Scholarship Repository.

https://scholarship.law.wm.edu/facpubs 


\title{
Punishing Pill Mill Doctors: Sentencing Disparities in the Opioid Epidemic
}

\begin{abstract}
Adam M. Gershowitz*
Consider two pill mill doctors who flooded the streets with oxycodone and other dangerous opioids. The evidence against both doctors was overwhelming. They each sold millions of opioid pills. Both doctors charged addicted patients hundreds of dollars in cash for office visits that involved no physical examinations and no diagnostic tests. Instead, the doctors simply handed the patients opioids in exchange for cash. To maximize their income, both doctors conspired with street dealers to import fake patients - many of them homeless - so that the doctors could write even more prescriptions. Both doctors made millions of dollars profiting off the misery of people addicted to opioids. Even though juries convicted both doctors of similar criminal charges, they received drastically different sentences. The first doctor was sentenced to five years, while the second doctor received a thirty-five-year sentence.

This Article reviews twenty-five of the worst opioid pill mill doctors to be sentenced in the last five years, and it details drastic sentencing disparities in the federal system. In more than half the cases, judges departed well below the Federal Sentencing Guidelines to impose sentences that were decades less than would be expected.

The sentencing variations in pill mill cases are not driven by traditional explanations such as the trial penalty or the defendant's criminal history. Instead, the sentencing variations are explained primarily by the age of the doctors. Many pill mill doctors are in their sixties and seventies, and judges appear to be tailoring their sentencing decisions to ensure that older doctors will not spend the rest of their lives in prison. Additionally, prosecutors face

* Copyright @ 2020 Adam M. Gershowitz. Hugh \& Nolie Haynes Professor of Law, William \& Mary Law School. I am grateful to Rachel Barkow, Jeff Bellin, Doug Berman, Eric Kades, and Ron Wright for big-picture suggestions about the sentencing of doctors and white-collar offenders. Fred Dingledy, Karly Newcomb, and Gabby Vance provided excellent research assistance.
\end{abstract}


an uphill battle in proving the drug quantity against white-collar doctors (rather than street dealers) who can claim that some of their prescriptions were legitimate. This Article documents the difficulty of equitably punishing pill mill doctors, as well as the significance of age in sentencing older, whitecollar offenders.

\section{TABLE OF CONTENTS}

INTRODUCTION 1055

I. Wide SENTENCING VARIATIONS FOR PILl Mill DOCTORS...... 1062

1. Dr. Pravin Mehta: 8,000 Patients, Clerical Staff Wrote Prescriptions, Two Years in Prison .............. 1063

2. Dr. Noel Blackman: 100 Patients per Day, 365,000 Pills in One Year, Four Years in Prison. 1065

3. Dr. Richard Evans: $\$ 240$ per Office Visit, 1.6 Million Pills, Five-Year Sentence 1066

4. Dr. Ernesto Lopez: One Million Pills, \$20 Million Street Value, Five-Year Sentence ............................. 1067

5. Dr. Alan Godofsky: Patients Paid Cash and "Always" Got Oxycodone, Five Years in Prison ...... 1069

6. Dr. Edward Ridgill: 700,000 Pills, File Cabinets Full of Cash, Five Years in Prison

7. Dr. Paul Ruble: Charged $\$ 200$ to $\$ 300$ per Prescription, Five Years in Prison 1072

8. Andrew Sun: 24,000 Prescriptions, $\$ 1$ Million in Illegal Profits, 5 1/4 Years in Prison.... 1073

9. Dr. Rodney Moret: Over One Million Pills, Drug Dealers Sold Pills in His Parking Lot, Six Years in Prison. 1075

10. Dr. Michael Minas: $\$ 100$ per Appointment, Easy Refills, High Dosages, Eight Years in Prison ............ 1077

11. Dr. Zongli Chang, 2.7 Million Pills, Fraudulent Medicare Billing, Eleven Years in Prison ................ 1078

12. Dr. Dwight Bailey: 14,000 Pills to One Patient, 12.5 Years in Prison. 1079

13. Dr. Carlos Venegas: Over Two Million Pills, Paid Homeless People to Act as Patients, Thirteen Years in Prison 1080

14. Dr. Daniel Cham: Prescriptions After Midnight, \$200 per Prescription, Thirteen Years in Prison...... 1081

15. Dr. Moshe Mirilashvili: 1.2 Million Pills, Made $\$ 2$ Million, 13 1/3 Years in Prison. 1083 
16. Dr. Christopher Stegawski: Broke into His Clinic After Police Had Closed It and Continued to Prescribe Pills, 13 1/3 Years in Prison.... 1085

17. Dr. Shelinder Aggarwal: 12.3 Million Pills, 423 Prescriptions per Day, Heath Care Fraud, Fifteen Years in Prison

18. Dr. Rafael Beier: Sold Prescriptions for $\$ 800$ each, Traded Sex for Drugs, Sixteen Years in Prison ........ 1087

19. Donovan Dixon: Conspired with Street Dealers to Use Fake Patients Names to Write Prescriptions, Twenty Years in Prison 1088

20. Dr. Tad Taylor: 12,000 Prescriptions, No Examinations, Twenty Years in Prison 1089

21. \& 22. Dr. John Couch and Dr. Xiulu Ruan:

Kickbacks, Illegitimate Pharmacy, Twenty and Twenty-One Years in Prison 1090

23. Dr. Timothy Gowder: Roughly Two Million Pills, \$1.7 Million in Profit, Twenty-One Years in Prison 1093 24. Dr. Sardar Ashrafkhan: Millions of Pills, Twenty-

Three Years in Prison 1093

25. Dr. Gazelle Craig: 3.5 Million Pills, Las Vegas

Cocktail, Thirty-Five Years in Prison. 1094

II. LONG SENTENCES FOR LESS EGREGIOUS MISCONDUCT ............ 1097

III. FACTORS THAT DO NOT EXPLAIN THE SENTENCING

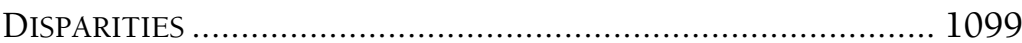

A. Criminal History Is a Largely Irrelevant Explanation ...... 1100

B. Sentences Did Not Become Longer in Later Years as the Opioid Crisis Became Well Known ....

C. Losing at Trial (Rather Than Pleading Guilty) Does Not Seem to Explain Sentencing Variations

D. Location of the Prosecution Does Not Explain Sentencing Variations.

IV. FACTORS THAT DO CONTRIBUTE TO SENTENCING DiSPARITIES 1109

A. The Difficulty of Computing Drug Quantity in Pill Mill

Cases Explains Some of the Sentencing Disparities .......... 1109

B. Age Appears to Play a Major Role in Sentencing Outcomes.

CONCLUSION.

\section{INTRODUCTION}

Many doctors fanned the flames of the opioid crisis by improperly prescribing drugs to patients who should not have received them. Some 
doctors were duped by drug-seeking patients. Other doctors sold small quantities of drugs on the side while maintaining otherwise legitimate medical practices. This Article is about a more egregious category of doctors - the pill mill physicians who wore white coats but were actually just drug dealers.

Most of the pill mill cases are strikingly similar. Doctors charged hundreds of dollars in cash for an initial appointment that lasted only a few moments. They then charged more money for refill visits that were even shorter in duration. ${ }^{1}$ The pill mill doctors made fortunes by putting millions of opioid pills on the street. ${ }^{2}$ When caught, they were almost always charged by federal prosecutors in federal court. ${ }^{3}$ And the evidence against them was typically overwhelming. ${ }^{4}$ In many cases,

1 See, e.g., United States v. Evans, 892 F.3d 692, 698 (5th Cir. 2018) ("[P]atients would get just one 30-day prescription from the visit. When their month-long supply of pills ran low, the patients would mail in $\$ 240$ money orders along with notes requesting a refill.").

2 See, e.g., id. at 699 ("Evans wrote over 11,000 prescriptions for oxycodone, coming out at over 1.6 million pills. Over that same period, Evans brought in over $\$ 2.4$ million ...."); Transcript of Sentencing Hearing at 27, United States v. Chang, No. 2:18-cr-20008 (E.D. Mich. July 1, 2019) [hereinafter Transcript of Sentencing Hearing, Chang] ("The amount paid to [Dr. Chang] for a visit ... was typically at least $\$ 150$, ranging as high as $\$ 400 \ldots . .$.$) ; Government's Second Supplemental Sentencing$ Memorandum at 3-4, United States v. Moret, No. 2:15-cr-20723 (E.D. Mich. Jan. 30, 2018) [hereinafter Government's Second Memorandum, Moret] (describing a doctor's practice of "prescribing the highest doses ... of narcotics ... paid for with cash"); Lawrence Specker, Dr. Xiulu Ruan Sentenced to 21 Years in Mobile 'Pill Mill' Case, AL.Com (May 26, 2017), https://www.al.com/news/mobile/2017/05/dr_xiulu_ruan_sentenced_ to_21.html [https://perma.cc/E3CJ-RDVZ] (describing a case in which a doctor was accused of performing fraudulent medical practices "designed to maximize the amount of money ... collected"); A Tennessee Physician, Two Florida Clinic Owners, and a Kentucky Man Convicted for Roles in Tennessee-Based Pill Mill Operation, U.S. DEP'T JusT. U.S. Attorney's OfF. E. District Ky. (Feb. 11, 2019), https://www.justice.gov/usaoedky/pr/tennessee-physician-two-florida-clinic-owners-and-kentucky-man-convictedroles [https://perma.cc/5XLC-LWWT] [hereinafter Two Florida Clinic Owners] (discussing the conviction of a doctor on both oxycodone-trafficking charges and money laundering charges); Georgia Doctor Pleads Guilty in Pill Mill Case, U.S. DeP'T Just. U.S. AtTORnEY's OfF. S. District GA. (Aug. 22, 2016), https://www.justice.gov/ usao-sdga/pr/georgia-doctor-pleads-guilty-pill-mill-case [https://perma.cc/XM4L-2EBT] [hereinafter Georgia Doctor Pleads] ("Ruble wrote prescriptions for vast quantities of controlled substances .... The unlawful business was very profitable ....").

3 This Article reports on twenty-five of the pill mill cases that attracted considerable media attention. All of them are federal prosecutions.

4 See, e.g., Transcript of Sentencing Hearing at 44, United States v. Dixon, No. 7:16-cr00030 (E.D.N.C. Feb. 11, 2019) (describing the evidence taken into account during the court's sentencing decision); Government's Sentencing Position Regarding Defendant Edward Ridgill at 11-12, United States v. Ridgill, No. 2:16-cr-00631 (C.D. Cal. Apr. 9, 2018) [hereinafter Government's Sentencing Position, Ridgill] ("[T]he evidence in this case 
undercover officers testified about office visits lasting under two minutes, and doctors letting them choose whatever drug they wanted. ${ }^{5}$ In some cases, surveillance and paper records showed doctors seeing up to 100 patients a day, but conducting little or no physical examinations or diagnostic tests. ${ }^{6}$ In numerous cases, the doctors were actually engaged in conspiracies to import fake patients, write them unnecessary prescriptions, transport them to pharmacies to fill the scripts, and to then reap profits from the opioids being sold on the streets. ${ }^{7}$

independently demonstrates defendant's culpability ... .."); Government's Sentencing Position Regarding Defendant Daniel Cham at 16, United States v. Cham, No. 2:14-cr-00591 (C.D. Cal. Nov. 16, 2016) [hereinafter Government's Sentencing Position, Cham] (noting "the overwhelming evidence regarding defendant's extensive involvement in issuing the sham prescriptions"); Doctor Convicted on Nine Counts in Connection with Oxycodone and Fentanyl Diversion Scheme, DRUG ENFORCEMENT ADMIN. (Feb. 22, 2019), https://www.dea.gov/press-releases/2019/02/22/doctor-convicted-nine-counts-connectionoxycodone-and-fentanyl-diversion [https://perma.cc/47XS-US8C] [hereinafter Doctor Convicted] (detailing the facts of the case as reflected by the evidence introduced at trial).

5 See, e.g., Transcript of Sentencing Hearing Proceedings at 13, United States v. Godofsky, No. 5:16-cr-00059 (E.D. Ky. May 29, 2018) [hereinafter Transcript of Sentencing, Godofsky] (describing the behavior observed by undercover officers who visited Dr. Godofsky's office); Indictment at 6, United States v. Mehta, No. 1:11-cr00268 (W.D.N.Y. Aug. 31, 2011) [hereinafter Indictment, Mehta] (describing Dr. Mehta's practice of "prescrib[ing] controlled substances as requested by patients"); Rick Pfeiffer, Former Falls Physician Pravin Mehta Sentence to Two Years, Niagara GazetTe (Jan. 25, 2016), https://www.niagara-gazette.com/news/crime/former-falls-physicianpravin-mehta-sentenced-to-two-years/article_2d17ff68-c385-1le5-aefe-7f2eef86966e.

html [https://perma.cc/XN3B-8YHJ] (describing the investigation of Pravin Mehta as "Operation Whatever U Want"); cf. 'Pill Mill' Operators Sentenced, U.S. DeP'T Just. U.S. AtTorney's OfF. S. District OHIO (Nov. 24, 2015), https://www.justice.gov/usaosdoh/pr/pill-mill-operators-sentenced [https://perma.cc/GZ78-6SHE] [hereinafter 'Pill Mill' Operators] (describing a case in which patients only received cursory examinations); Pill Mill Physician Sentenced to 13 Years for Conspiracy to Distribute Narcotics, U.S. Dep’t Just. U.S. Attorney's Off. N. District Tex. (May 13, 2019), https://www.justice.gov/usao-ndtx/pr/pill-mill-physician-sentenced-13-years-conspiracydistribute-narcotics [https://perma.cc/WF6E-DDC2] [hereinafter Pill Mill Physician] (describing Dr. Venegas' practice of "conduct[ing] only cursory medical exams").

6 See Transcript of Proceedings Before the Honorable Michael R. Barrett at 29, United States v. Stegawski, No. 1:12-cr-00054 (S.D. Ohio May 9, 2016) [hereinafter Transcript of Proceedings, Stegawski]; see, e.g., Phil Fairbanks, Pravin Mehta, 'Dr. Feel Good,' Gets Prison for Dealing Opiate Pills, BufF. NEws (Jan. 25, 2016), https://buffalonews.com/news/local/pravin-mehta-dr-feel-good-gets-prison-for-dealingopiate-pills/article_d2a8824d-1fce-53fc-b393-718aee962a2b.html [https://perma.cc/5YEAH8BN] ("[Mehta] admitted handing out prescriptions without a proper medical reason and sometimes without doing even a basic exam.").

7 See, e.g., Transcript of Sentencing Hearing, Chang, supra note 2, at 26-27 (describing a doctor's practice of prescribing controlled substances to "quote, unquote patient[s]"); Government's Sentencing Position for Defendant Andrew Sun at 19, United States v. Sun, No. 2:14-cr-00157 (C.D. Cal. Nov. 7, 2014) (describing the 
Most pill mill doctors were charged and convicted of unlawful distribution of controlled substances with no legitimate medical purpose under 21 U.S.C. $\& 841 .^{8}$ That is the same statutory provision that street offenders - those dealing heroin on the street or cocaine in a back alley - are convicted of every day in the United States. ${ }^{9}$ Doctors, of course, are authorized to prescribe controlled substances because they have a license issued by the Drug Enforcement Administration ("DEA"). 10 But federal regulations and case-law provide that a prescription is not valid if it is not for a legitimate medical purpose and in the usual course of professional practice. ${ }^{11}$ Put simply, when doctors issue an illegitimate prescription they are selling drugs and can be prosecuted under federal law.

Each drug distribution count carries a sentence of up to twenty years in prison. ${ }^{12}$ That, of course, is a broad sentencing range. Within that

defendant's participation in "capping" activity, in which doctors "facilitated drug dealers' acquisition of controlled drugs for sales on the street"); Pill Mill Physician, supra note 5 (describing a situation in which the conspirators paid homeless and indigent individuals to be fake patients).

821 U.S.C. $\& 841$ (2018). Section 841 is a commonly invoked federal drug statute used to prosecute not only doctors but, much more commonly, street dealers engaged in the sale of heroin, cocaine, marijuana, and other illegal narcotics.

9 Drug offenses are the second most common federal crime, after immigration offenses. The United States Sentencing Commission reported nearly 20,000 drug cases for the year 2018 with most of them involving manufacture, sale, or transportation and less than 1,000 involving simple possession. See U.S. SENTENCING COMM'N, OvERVIEW OF FEDERAL CRIMINAL CASES 13 (2019), https://www.ussc.gov/sites/default/files/pdf/research-and-publications/ research-publications/2019/FY18_Overview_Federal_Criminal_Cases.pdf [https://perma. cc/3E6U-L54C].

1021 U.S.C. \& 822(b) (2018).

1121 C.F.R. § 1306.04(a) (2020); see also United States v. Moore, 423 U.S. 122, 131-32 (1975) (concluding that registration protects only lawful acts of prescribing).

12 See 21 U.S.C. \& 841. This article does not consider cases in which prosecutors successfully "charged the death" and held doctors responsible for a patient's overdose. Under federal drug law, if a victim dies as a result of drugs - whether it be street drugs or a prescription that comes in a bottle - the doctor faces a sentence of up to life, with a mandatory minimum sentence of twenty years. See id. $\$ 841(b)(1)(A)(v i i i)$. Prosecutors do not frequently invoke this provision in doctor prosecutions - that is, they do not often "charge the death" - because it is difficult to prove that a drug sold or prescribed by the defendant was the indisputable cause of death. See Burrage v. United States, 571 U.S. 204, 216 (2014) ("The language Congress enacted requires death to 'result from' use of the unlawfully distributed drug, not from a combination of factors to which drug use merely contributed."). In a few high-profile cases though, prosecutors have successfully brought such charges. For instance, Dr. Joel Smithers was sentenced to forty years in prison in 2019 after being convicted at trial of 800 counts of distribution of controlled substances, including one case in which the drugs caused the death of the victim. Adeel Hassan, A Doctor Who Prescribed 500,000 Doses of Opioids Is Sent to Prison for 40 Years, N.Y. TIMES (Oct. 2, 2019), https://www.nytimes.com/ 
wide statutory range, it falls to the Federal Sentencing Guidelines to help judges determine a fair sentence. ${ }^{13}$ The guidelines were designed — in meticulous detail - to ensure that similar defendants would be punished similarly. ${ }^{14}$ This should be particularly true in drug cases, where it is possible to make apples-to-apples comparisons about drug quantities. We should therefore expect that in federal pill mill cases with similar conduct, similar criminal charges, and similarly overwhelming evidence - that the doctors would receive similar punishments.

But the punishments for pill mill doctors - the doctors we can agree were the worst of the worst - have been anything but similar. To the contrary, the sentences have been wildly inconsistent. In analyzing twenty-five of the worst pill mill doctors who were sentenced in the last few years, this Article demonstrates that some doctors received sentences of five years or less while other doctors were sentenced to 15, 20 , and even 35 years in prison. And the factors we might think of to explain the inconsistencies - the location or timing of the prosecutions, or the decision to go to trial rather than plead guilty do not appear to explain the sentencing disparities.

The primary reason why pill mill doctors are receiving inconsistent punishments is age. Unlike most criminal defendants who are under the age of thirty, ${ }^{15}$ the average doctor charged with distributing opioids is

2019/10/02/us/opioids-doctor-sentenced-joel-smithers.html [https://perma.cc/4GKWXA7M]; see also Max Bennett, Ex Doctor's Deadly Pill Ring Ends in Prison Time: U.S. Attorney, PATCH (June 15, 2017, 2:19 PM ET), https://patch.com/pennsylvania/ philadelphia/amp/27132902/ex-doctors-deadly-pill-ring-ends-in-prison-time-u-sattorney [https://perma.cc/EEF2-S88Y] (discussing Dr. Jeffrey Bado's twenty-five-year sentence). Because these cases are less common and because they are subject to mandatory minimum sentences of twenty years, I have omitted them from analysis in this Article.

13 In the aftermath of the Booker decisions, the Federal Sentencing Guidelines are no longer binding. See United States v. Booker, 543 U.S. 220, 222 (2005).

14 See U.S. Sentencing Comm'n, Guidelines Manual ch. 1, pt. A, introductory cmt. (2018), https://www.ussc.gov/sites/default/files/pdf/guidelines-manual/2018/GLMFull.pdf [https://perma.cc/F7KS-FUUR] ("Congress sought reasonable uniformity in sentencing by narrowing the wide disparity in sentences imposed for similar criminal offenses committed by similar offenders."); Susan R. Klein \& Jordan M. Steiker, The Search for Equality in Criminal Sentencing, 2002 Sup. Cт. REv. 223, 232-33 ("The Federal Sentencing Guidelines have achieved their highest level of success regarding Congress's stated goal - the reduction of unwarranted disparity in sentencing.").

15 See Loren A.N. Buddress, Federal Probation and Pretrial Services: A Cost-Effective and Successful Community Corrections System, 61 FED. ProB. 5, 8 (1997) ("A typical criminal career begins when the person is approximately 14 years of age and increases until the early twenties. After that, it decreases until approximately 30, when most criminal careers decline."). 
in his sixties. Of the roughly 200 doctors who have been sentenced for illegally distributing opioids in the last five years, more than seventy were over the age of sixty. ${ }^{16}$ The Federal Sentencing Guidelines have a specific provision - $\$ 5 . \mathrm{H1} .1$ - that allows judges to take account of a defendant's advanced age in rare cases when imposing a sentence. ${ }^{17}$ Yet in pill mill cases, judge appear to be considering age frequently, rather than rarely. Judges appear reluctant to impose a lengthy sentence even one called for under the guidelines - on an elderly doctor because it would almost certainly mean he would die in prison. Yet, the judge may have no such hesitation about imposing a lengthy sentence on a forty-five-year-old doctor convicted of the same misconduct. Judges who want to avoid having doctors die in prison thus impose long sentences on younger doctors and short sentences on older doctors. ${ }^{18}$ Age thus plays a major role in sentencing disparities for pill mill doctors.

A second reason for sentencing disparities in pill mill cases is the difficulty in determining the drug quantity in cases involving doctors, as opposed to street dealers. The Federal Sentencing Guidelines contain a conversion chart that determines a recommended sentence based on the type of drug and the weight of the drug. ${ }^{19}$ For street drug cases, it is fairly simple to determine the quantity in most cases. Bags of cocaine found in a stash house are weighed and the entire drug weight is counted toward the defendant's sentence. ${ }^{20}$

Pill cases are harder, however. ${ }^{21}$ If a doctor writes a legitimate prescription, those pills cannot be counted toward the total drug

16 See Adam M. Gershowitz, Old Age as the Hidden Sentencing Factor (forthcoming 2021) (manuscript at 2, 11-18) (on file with author) (providing ages at sentencing of a sample of 129 doctors convicted in federal court of illegally distributing opioids).

17 See U.S. Sentencing Comm'n, U.S. Sentencing Guidelines Manual \& 5H1.1 (2018); see also Evan A. Jenness, The 'Silver Tsunami' and Sentencing: Age and Health as Mitigating Factors, 37 CHAMPION 30, 30 (Sept./Oct. 2013).

18 See Gershowitz, supra note 16 , at 1 .

19 Under prior versions of the Sentencing Guidelines drug weight was converted to marijuana equivalent grams and then plugged into the sentencing table. More recent versions of the guidelines simply call this the "converted drug weight," without reference to marijuana. U.S. SENTENCING COMM'N, PRIMER: DRUG GUIDELINES 5-6 (2020), https://www.ussc.gov/sites/default/files/pdf/training/primers/2020_Primer_Drugs.pdf [https://perma.cc/4TUG-SL8H].

20 See, e.g., United States v. Ramirez-Maldonado, 928 F.3d 702, 708 (8th Cir. 2019) (upholding district judge's decision to count full drug quantity from a stash house).

21 See, e.g., Transcript of Sentencing Before the Honorable Kenneth M. Hoyt at 27, United States v. Evans, No. 4:15-cr-00015 (S.D. Tex. Apr. 13, 2017) [hereinafter Transcript of Sentencing, Evans] (quoting defense attorney saying "So the question on how wide to cast the relevant conduct, Judge .... If this was heroin, we would say if there is proof that he had 900 customers, we wouldn't be arguing about relevant conduct 
weight. Prosecutors must therefore prove that the prescriptions were illegitimate in order to count them toward the drug quantity. ${ }^{22}$ This means prosecutors must reconstruct the history of the doctor's medical practice to figure out the number of patients and the quantity of pills prescribed. It also means prosecutors must hire medical experts other doctors - to opine about which patients should and should not have been prescribed opioids. In some cases, prosecutors undertake the massive time and expense to determine the full drug quantity. In other cases, prosecutors take a simpler path by counting only a small number of obviously illegal prescriptions. These different approaches lead to sentencing disparities.

Of course, there may be other reasons for the sentencing variations among pill mill doctors. Some doctors can point to prior charitable works. ${ }^{23}$ Others likely have high-priced and very effective lawyers. And judges may identify on a subconscious level with some of the doctors who may have moved in similar social circles. ${ }^{24}$ These explanations are speculative, however. By contrast, time and again, there is evidence in pill mill cases that the age of the doctors and the difficulty of computing drug quantity appears to drive sentencing variations.

because there is no excuse for heroin. There is no legitimate purpose for heroin, but we are dealing with a legal drug.").

22 See infra Part IV.

23 See, e.g., Government's Sentencing Memorandum at 1, United States v. Blackman, No. 2:16-cr-00089 (E.D.N.Y. May 9, 2017) [hereinafter Government's Sentencing Memorandum, Blackman] ("Blackman urges this Court to impose a non-Guidelines sentence of imprisonment because of his past charitable works .....").

24 There has long been speculation that the criminal justice system treats whitecollar offenders more favorably than street offenders. That may simply be factually incorrect though. See generally Samuel W. Buell, Is the White Collar Offender Privileged?, 63 DUKE L.J. 823 (2014) (arguing that substantive criminal law and the recent sentencing trends show a lack of favoritism). Nevertheless, there is evidence that certain types of white-collar offenses lead to below-guidelines sentences. See generally Jillian Hewitt, Note, Fifty Shades of Gray: Sentencing Trends in Major White-Collar Cases, 125 YALE L.J. 1018 (2016) (studying white-collar offenses from the Southern District of New York and finding below-guidelines sentences, with a particular focus on cases involving economic loss). Doctors convicted of drug dealing occupy a strange position in the white-collar discussion. On the one hand, they are highly educated, typically affluent, and thus appear to be the quintessential white-collar offenders. On the other hand, they stand convicted of drug dealing, a classic "street crime." This Article is not framed as a comparison between white-collar and street offenders. Rather, this Article focuses on (arguably related) factors such as age and the difficulty of proving drug quantity in pill cases. 
This Article explores inconsistent sentencing by analyzing twentyfive of the worst pill-mill doctors to be sentenced in the last few years. ${ }^{25}$ Part I describes cases in which doctors charged hundreds of dollars in exchange for prescriptions, prescribed millions of pills, conducted no physical examinations, conspired with street dealers to bring in fake patients, and accepted kickbacks from opioid drug manufacturers. While the facts of each case differ, they are similarly appalling. Yet, the sentences range from two to thirty-five years in prison with very little rhyme or reason for the variations. Part II provides additional context by considering some less egregious cases in which doctors appeared to be running legitimate medical practices but selling opioids on the side. Strikingly, the doctors in these less egregious cases received longer sentences than many of the pill mill doctors. Finally, Part III explores the reasons why disparities may be occurring. Part III first rules out conventional explanations such as the trial penalty or the possibility that sentences became tougher over time as the scale of the opioid crisis became better known. Part III then explains the factors that do appear to actually be driving the sentencing variations: the age of the doctors and the difficulty prosecutors face in proving that all of the drugs were illegally prescribed.

\section{Wide SENTENCING VARIATIONS FOR Pill Mill DOCTORS}

In this Part, I review twenty-five of the most egregious pill mill doctors who were sentenced across the country from 2015 to 2019. The conduct of these doctors was not identical, though there are many similarities. All of the doctors wrote huge numbers of illegal prescriptions for massive numbers of pills. They were working out of doctors' offices, but they were not providing what we think of as medical care. In most cases, the doctors performed no physical examinations or legitimate diagnostic tests. Instead, "patients" paid cash — often hundreds of dollars — for office visits that lasted only a

25 Hundreds of doctors have been sentenced for improperly distributing opioids in recent years. See Gershowitz, supra note 16, at 5 . Selecting the worst cases obviously involves a degree of subjectivity. The amount of publicly available information also played a major role in deciding whether to include a case. It was difficult to include cases in which plea agreements, sentencing memoranda, and sentencing transcripts were sealed, especially if there was limited news coverage of the cases. I therefore focused on cases in which there was ample documentation that doctors prescribed huge numbers of pills, exchanged cash for pills, performed no examinations, sold drugs at irregular hours, employed bouncers to control the drug-seeking populations, imported fake patients, and engaged in other egregious misconduct. I am cognizant that readers might reach different conclusions though about which cases should have been included or excluded in the analysis. 
few moments. The doctors asked the "patients" what drugs they wanted, and the doctors then wrote the prescriptions. And the doctors reaped huge profits from this illegitimate prescribing.

Of course, there were differences in the cases and we should therefore expect some sentencing variations as a result. First, some doctors prescribed millions of pills, compared with "only" hundreds of thousands of pills for other doctors. Second, some doctors opened their doors and allowed drug-seeking patients to walk through the door, while other doctors actively conspired to import fake patients and transport them to pharmacies to fill the illegal prescriptions. Third, some doctors simply accepted cash payments for the drugs and hid the money in file cabinets. Other doctors engaged in additional egregious behavior such as money laundering or fraudulently billing insurance companies for tests that were never performed. Fourth, some doctors plead guilty and accepted responsibility for their misconduct, while other physicians continued to lie and were convicted at trial.

It would not be the least bit surprising to see some sentencing variations based on the differences in the doctors' behavior and the number of pills they prescribed. Yet, as the cases below demonstrate, the sentencing variations are massive. And they often do not correlate with the aggravating and mitigating factors present in the cases. I proceed in ascending order from the shortest to the longest sentences. The story begins with a seventy-seven-year-old general practitioner who was pre-signing prescription pads and allowing clerical workers who were addicted to drugs to write prescriptions. That single doctor was seeing 8,000 patients, more than triple the number handled by most general practitioners. He received a sentence of two years - far less than many doctors who committed similar misconduct.

\section{Dr. Pravin Mehta: 8,000 Patients, Clerical Staff Wrote Prescriptions, Two Years in Prison}

In early 2011, law enforcement agents arrested Dr. Pravin Mehta and more than a dozen of his office staff and patients as part of "Operation Whatever U Want."26 Prosecutors charged Dr. Mehta - who was known in the community as "Dr. Feel Good" - with conspiracy and twenty-seven counts of illegally distributing a controlled substance. ${ }^{27}$

After more than four years of litigation, Dr. Mehta plead guilty only to the charge of conspiracy to possess with intent to distribute

26 Pfeiffer, supra note 5.

27 See id. See generally Indictment, Mehta, supra note 5 (discussing all twenty-seven counts). 
oxycodone. ${ }^{28}$ In pleading guilty, Dr. Mehta admitted that he prescribed opioids that were not medically necessary and without conducting physical examinations. ${ }^{29} \mathrm{He}$ acknowledged pre-signing prescription pads so that his office staff could write prescriptions while he was out of the country. ${ }^{30}$ Moreover, Dr. Mehta did not employ any nurses or physician assistants; the prescriptions were written "entirely [by] clerical workers, some of whom abused prescriptions drugs and utilized the blank forms to feed their own habit or be sold to others." 31

Dr. Mehta admitted that he illegally dispensed pills for over three years. ${ }^{32}$ According to news reports, police were alerted to Dr. Mehta's illegal operation because there were lines outside of his office building that included "users and dealers looking for an easy way to score some pills." 33 Dr. Mehta had more than 8,000 patients, which was triple the number of the average general practitioner. ${ }^{34}$ According to prosecutors, Dr. Mehta charged $\$ 50$ to $\$ 80$ per patient visit, and patients dictated which drugs they wanted. ${ }^{35}$ The large volume of patients enabled Dr. Mehta to take home a large amount of money. ${ }^{36}$ One news report placed his net worth at $\$ 13$ million, ${ }^{37}$ and the government argued that his decision to treat such a large number of patients and not to hire nurses was simply driven by greed. 38

The plea agreement contemplated a guidelines range of fifty-one to seventy-one months, and when the probation office prepared the presentence report it agreed with that calculation. ${ }^{39}$ At sentencing, the district judge "offered an unusually long statement on Mehta's conduct" and suggested more than once that Dr. Mehta was partly responsible for the opioid crisis. ${ }^{40}$ Yet, the court departed below the guidelines and

28 Plea Agreement at 1, United States v. Mehta, No. 1:11-cr-00268 (W.D.N.Y. May $14,2015)$.

29 Id. at 3.

$30 \mathrm{Id}$.

31 Government's Response to the Defendant's Request for a Non-Guidelines Sentence at 4, United States v. Mehta, No. 1:11-cr-00268 (W.D.N.Y. Jan. 22, 2016) [hereinafter Government's Response, Mehta].

32 Fairbanks, supra note 6.

33 Id.

34 Id.

35 See Government's Response, Mehta, supra note 31, at 5-6.

36 See id. at 6.

37 See Fairbanks, supra note 6.

38 See Government's Response, Mehta, supra note 31, at 4-6.

39 Id. at 2.

40 Fairbanks, supra note 6. 
sentenced Dr. Mehta to twenty-four months in prison — less than half of the recommended sentence. ${ }^{41}$

One likely explanation for the lighter sentence is Dr. Mehta's age he was seventy-seven years old at sentencing. ${ }^{42}$ Although it is impossible to know for sure, it seems likely that the judge imposed a two-year sentence to ensure that Dr. Mehta would leave prison before turning eighty.

2. Dr. Noel Blackman: 100 Patients per Day, 365,000 Pills in One Year, Four Years in Prison

In the year 2015 alone, Dr. Noel Blackman wrote 2,487 prescriptions for more than 365,000 pills of oxycodone. ${ }^{43}$ Working out of numerous pain management clinics, he provided oxycodone prescriptions in exchange for $\$ 300$ in cash. On a typical day, Dr. Blackman would see approximately 100 patients - the equivalent of one patient every six minutes. ${ }^{44}$ As agents closed in on him, he was caught boarding a flight to Guyana with a one-way ticket and $\$ 30,000$ in cash. ${ }^{45}$

Dr. Blackman eventually plead guilty to a single count of distributing oxycodone. ${ }^{46}$ At his plea colloquy, Dr. Blackman admitted that he wrote 1,920 illegal oxycodone prescriptions ${ }^{47}-\mathrm{a}$ fraction of the alleged misconduct.

Based on the smaller agreed drug quantity, the prosecution and defense agreed on a sentencing guidelines range of fifty-seven to seventy-one months. ${ }^{48}$ The Government argued for the top end of the range - seventy-one months - because Dr. Blackman was "prescribing massive amounts of oxycodone, maintaining slipshod records" and clearly knew he was engaged in criminal activity given that he had also graduated from law school. 49

41 See id.

42 See id.

43 Government's Sentencing Memorandum, Blackman, supra note 23, at 2.

44 See Robert E. Kessler, L.I. Pain Doctor Sentenced to 50 Months in Oxycodone Case, NewSDAY (May 12, 2017, 6:59 PM), https://www.newsday.com/long-island/crime/lipain-doctor-sentenced-to-50-months-in-oxycodone-case-1.13626691 [https://perma.cc/ YW9S-MPYJ].

45 Government's Sentencing Memorandum, Blackman, supra note 23, at 2.

46 See Criminal Cause for Guilty Plea at 1, United States v. Blackman, No. 2:16-cr00089 (E.D.N.Y. Aug. 24, 2016).

47 See Government's Sentencing Memorandum, Blackman, supra note 23, at 2.

48 See id. at 1.

49 Id. at 3. 
The court departed below the guidelines range, however, and imposed a sentence of fifty months. ${ }^{50}$ It is possible the court was influenced by the lengthy statement of his prior charitable works and his advanced age of sixty-eight. ${ }^{51}$

3. Dr. Richard Evans: $\$ 240$ per Office Visit, 1.6 Million Pills, FiveYear Sentence

Dr. Richard Arthur Evans ran a pain management clinic in Houston that had all the hallmarks of a pill mill. Employees from another office in the building noticed that cars with Louisiana license plates that were "loaded with up to six people" would show up at Dr. Evans's office and that they would outnumber the cars with Texas license plates. ${ }^{52}$ When the employees would unlock the building in the morning they would see people waiting outside, and people would loiter around the building for the rest of the day. ${ }^{53}$ Witnesses noticed that many of the "patients" were unkempt, that they would "use the wrong restroom or try to take baths in the sinks." 54 Witnesses also observed a patient washing and drying her hands over and over again. ${ }^{55}$ And they saw another patient leave Dr. Evans' office "shaking a prescription with glee because he 'got it." 56 These behaviors are all hallmarks of drug addiction.

Witnesses looked through Dr. Evans' trash and found "torn and retaped prescriptions and handwritten letters requesting prescriptions (dosage and pill count often included)." 57 They also found a flyer directing patients to arrange to mail order their prescriptions from a pharmacy that was "the number one pharmacy in Texas for purchasing oxycodone ... in 2011."58 Dr. Evans' prescriptions accounted for over $50 \%$ of the pharmacy's prescriptions. 59

Dr. Evans was charged with conspiracy, distributing controlled substances without a legitimate medical purpose, money laundering, and mail fraud. ${ }^{60}$ At trial in 2016, the evidence demonstrated that his

50 See Kessler, supra note 44.

51 See Defendant's Sentencing Memorandum at 5-11, United States v. Blackman, No. 2:16-cr-00089 (E.D.N.Y. May 4, 2017).

52 United States v. Evans, 892 F.3d 692, 696 (5th Cir. 2018).

53 Id.

54 Id.

55 Id.

56 Id.

57 Id. at 697.

58 Id. at $697,699$.

59 Id. at 699.

60 Id. at 697. 
staff were pre-signing prescriptions before Dr. Evans examined patients and that patients were instructed to mail in $\$ 240$ money orders in exchange for prescription refills. ${ }^{61}$ The evidence demonstrated that from 2010 to 2012 Dr. Evans wrote 11,000 prescriptions for oxycodone — over 1.6 million pills — which brought in over $\$ 2.4$ million in cash, money orders, and checks. ${ }^{62}$ The jury convicted Dr. Evans on all counts. ${ }^{63}$

At sentencing, the Assistant United States Attorney made an impassioned plea that the judge not take mercy on Dr. Evans. According to the prosecutor, the guidelines range for Dr. Evans was 324 to 405 months based on the huge quantity of pills he distributed. ${ }^{64}$ The prosecutor suggested a sentence below that recommended guidelines range - a sentence of at least 180 months. ${ }^{65}$

However, the judge devised his own questionable formula to determine the quantity of Dr. Evans' prescriptions that were unlawful. ${ }^{66}$ After calculating a much lower quantity of drugs, the judge reached a sentencing range of seventy to eighty-seven months. ${ }^{67}$ But the judge did not sentence Dr. Evans in that range. The court concluded that Dr. Evans' age - he was seventy-two years old — as well as his volunteer work and faith in God justified a sentence below the guidelines range. ${ }^{68}$ In particular, the judge noted that "the Court does not and is not of the opinion that a sentence that would place a 72 -year-old man in prison for life essentially would be an appropriate sentence." 69 The judge therefore imposed a sentence of sixty months' incarceration..$^{70}$ Not surprisingly, the prosecutors described this sentence as "extremely lenient."71

4. Dr. Ernesto Lopez: One Million Pills, \$20 Million Street Value, Five-Year Sentence

Dr. Ernesto Lopez wrote thousands of medically unnecessary prescriptions for not only oxycodone but also the far more dangerous

61 See id. at 698.

62 Id. at 699.

63 See id. at 702.

64 See Transcript of Sentencing, Evans, supra note 21, at 42.

65 Id.

66 See id. at 57-58.

67 See id. at 57, 60.

68 See id. at 60-61.

$69 \mathrm{Id}$. at 61.

70 Id. at 58.

71 Id. at 63. 
drug, fentanyl. ${ }^{72}$ Dr. Lopez wrote prescriptions for nearly one million oxycodone pills, which the DEA said had a street value of roughly $\$ 20$ million. ${ }^{73}$ He also wrote 2,300 prescriptions for fentanyl patches or sprays. ${ }^{74}$ Dr. Lopez typically charged patients $\$ 200$ to $\$ 300$ in cash for each visit, even though almost $80 \%$ of his patients had health insurance. ${ }^{75}$ For many patient visits, Dr. Lopez did not perform real physical examinations and instead simply prescribed 120 oxycodone pills at a time or fentanyl patches. ${ }^{76}$ When DEA agents arrested him, they recovered "hundreds of fentanyl sprays and patches from his residence, along with approximately $\$ 729,000$ in cash in boxes." 77

A jury convicted Dr. Lopez of conspiracy to distribute oxycodone and fentanyl as well as eight counts of distributing oxycodone without a legitimate medical purpose..$^{78}$ Based on the massive drug quantities, the Federal Probation Office calculated a guidelines range of 360 months to life ${ }^{79}$ which is the second-highest category in the Federal Sentencing Guidelines. The Probation Office recommended a below-Guidelines sentence of ninety-six months and the U.S. Attorney's Office recommended a sentence "at or above Probation's recommended sentence of 96 months' imprisonment." 80

At sentencing, Dr. Lopez's lawyers focused on his poor health and two minor strokes he had recently had. ${ }^{81}$ Defense attorneys speculated (without any medical testimony) that Dr. Lopez personally believed "he probably has about five or less years [left] to live." 82 The Government suggested that Dr. Lopez was malingering and exaggerating his health problems. ${ }^{83}$ And the Government presented testimony from a physician that Dr. Lopez had made a full recovery from the first stroke and that

72 See Doctor Convicted, supra note 4.

73 Id.

74 Government's Sentencing Memorandum at 4, United States v. Lopez, No. 1:18cr-0006 (S.D.N.Y. June 25, 2019) [hereinafter Government's Sentencing Memorandum, Lopez].

75 Doctor Convicted, supra note 4.

76 See id.

77 Id.

78 See id.

79 See Transcript of Sentencing Hearing at 3, United States v. Lopez, No. 1:18-cr0006 (S.D.N.Y. July 12, 2019) [hereinafter Transcript of Sentencing, Lopez].

80 Government's Sentencing Memorandum, Lopez, supra note 74, at 10, 31.

81 See Transcript of Sentencing, Lopez, supra note 79, at 13-18.

82 See id. at 46.

83 See id. at 20-21. 
he was "exaggerating his deficits." ${ }^{4}$ The judge was appalled by Dr. Lopez's misconduct, noting that:

[T] he defendant [has failed] to express any remorse. ... How anyone could do what he did, I'm not quite sure. But to keep junkies supplied with drugs when you could see it was destroying their lives, to keep drug dealers supplied with these drugs when you knew it was going to be destroying other people's lives, and all for the sake of greed, is extraordinary. It was so painful to sit through this testimony. So profoundly disturbing. ... So the defendant is a drug dealer who has shown no remorse, no understanding of the enormity of the criminal activity in which he's engaged.... I find there is reason to believe that he's a malingerer and is exaggerating his health condition . . . .85

The court nevertheless saw the need to give considerable attention to Dr. Lopez's age - seventy-five years old - and his health issues. ${ }^{86}$ Despite the massive number of pills, the dangerous fentanyl prescriptions, and the evidence he was malingering, the judge sentenced Dr. Lopez to roughly half what the Probation Office and prosecutors recommended. Dr. Lopez received five years in prison. ${ }^{87}$

\section{Dr. Alan Godofsky: Patients Paid Cash and "Always" Got Oxycodone, Five Years in Prison}

Dr. Alan Godofsky was hired to work at a pill mill clinic in central Kentucky. Multiple doctors worked at the clinic and "hundreds of patients were being seen per day." 88 The patients paid cash and "they always got oxycodone." 89 In recounting trial testimony, the court explained that the "clinic manager [would walk] around armed with a German Shepherd dog patrolling the clinic" and that "it's hard to imagine that anybody ... would not have a sense of what was going on here and his responsibility in participating in the overall scheme." 90

84 See id. at 19-21.

85 Id. at $51-53$

86 See id. at 53 .

87 Doctor Who Operated Oxycodone and Fentanyl Diversion Scheme Sentenced to 5 Years in Prison, DRUG ENFORCEMENT ADMIN. (July 2, 2019), https://www.dea.gov/pressreleases/2019/07/02/doctor-who-operated-oxycodone-and-fentanyl-diversion-schemesentenced-5 [https://perma.cc/V838-3QYU].

88 Transcript of Sentencing, Godofsky, supra note 5, at 14.

89 Id.

$90 \mathrm{Id}$. 
At trial, the evidence indicated that Dr. Godofsky was a key part of the pill mill operation. His primary activity at the clinic was to write prescriptions for oxycodone pills. Dr. Godofsky saw seventy patients per day. ${ }^{91} \mathrm{He}$ "conducted minimal exams, spending very little time with patients (some who were cooperating witnesses for the government) before prescribing large quantities of oxycodone pills." 92 Although he only worked at the clinic for a "relatively brief" time, Dr. Godofsky prescribed more than 500,000 oxycodone pills. ${ }^{93}$

Yet, Dr. Godofsky was not held responsible for the 500,000 pills. As the prosecutor explained at sentencing:

The number of pills that Dr. Godofsky is being held responsible for really could be substantially higher had the United States essentially gone through the entire patient list and sought out each of those patients during the time frame to be considered relevant conduct. He has already received a more than substantial break considering that the amount of pills attributable to him is far less than the 500,000 pills that he distributed during that course of time that he was at that clinic. ${ }^{94}$

The court agreed that the defendant "received a break in terms of the drug quantity" and set the guidelines range at 121 to 151 months.95 Nevertheless, the court imposed a sentence well below that guidelines range. Noting that even a shorter sentence would "probably take the best of the rest of this defendant's life from him, given his age" the court imposed a sentence of sixty months. ${ }^{96}$ Dr. Godofsky, who was sixty-one years old at sentencing, ${ }^{97}$ will therefore leave prison by age sixty-six.

91 Id. at 28

92 Cincinnati Physician Sentenced to 60 Months for Illegal Distribution of Oxycodone Pills, U.S. Dep't Just. U.S. Attorney's Off. E. District Ky. (Apr. 26, 2018), https://www.justice.gov/usao-edky/pr/cincinnati-physician-sentenced-60-months-illegaldistribution-oxycodone-pills [https://perma.cc/HP24-833E] [hereinafter Cincinnati Physician Sentenced].

93 Id.

94 Transcript of Sentencing, Godofsky, supra note 5, at 29.

95 Id. at 16,32

96 Id. at 33.

97 Cincinnati Physician Sentenced, supra note 92. 
6. Dr. Edward Ridgill: 700,000 Pills, File Cabinets Full of Cash, Five Years in Prison

It took a jury only about thirty minutes to convict Dr. Edward Ridgill of twenty-six counts of distributing controlled substances without a legitimate medical purpose. ${ }^{98}$ The evidence presented at trial demonstrated that Dr. Ridgill wrote nearly 9,000 prescriptions in the year 2014 alone. Even more alarming, 95\% of those prescriptions were for three drugs - Norco, Xanax and Soma - which create "the most sought-after drug cocktail on the black market, and one for which there is no legitimate medical purpose." 99 Dr. Ridgill's prescriptions amounted to over 700,000 dosage units. ${ }^{100}$ Patients sometimes traveled more than 100 miles to obtain prescriptions. ${ }^{101}$ When agents searched Dr. Ridgill's medical office, they found file cabinets with cash in them and even found cash inside some patient files. ${ }^{102}$ Shockingly, this was not Dr. Ridgill's first conviction for improperly using his medical license. In the 1990s, a jury convicted him of seven counts of mail fraud arising out of a scheme to defraud California of insurance funds by falsely certifying patients as disabled. 103

At sentencing, the Government relied only on prescription data from a single year and estimated a total of about 9,000 prescriptions. ${ }^{104}$ The prosecutor explained that "[i]f the Government actually covered the entirety of defendant's prescription history ... the offense level [and thus the guidelines range] would be ... through the roof." 105

98 See Medical Doctor Who Illegally Wrote Prescriptions - Including for Highly Addictive Opioids - Sentenced to Five Years in Prison, U.S. DeP’t Just. U.S. AtTORneY's OfF. Cent. District CAl. (Apr. 23, 2018), https://www.justice.gov/usao$\mathrm{cdca} / \mathrm{pr} /$ medical-doctor-who-illegally-wrote-prescriptions-including-highly-addictiveopioids [https://perma.cc/T3SV-2Y6A] [hereinafter Medical Doctor Sentenced to Five Years].

99 City News Serv., Ex-Doctor Sentenced to Five Years for Selling Prescriptions in Lynwood, NBC L.A. (Apr. 23, 2018), https://www.nbclosangeles.com/news/local/ExDoctor-Sentenced-to-Five-Years-for-Selling-Prescriptions-in-Lynwood-480603791.html [https://perma.cc/N8XG-TMGB] [hereinafter Ex-Doctor Sentenced].

100 See Government's Sentencing Position, Ridgill, supra note 4, at 11.

101 See City News Serv., Ex-Doctor Sentenced, supra note 99.

102 See id.

103 See United States v. Ridgill, No. 98-50668, 1999 WL 510834, at *1 (9th Cir. 1999).

104 Reporter's Transcript of Sentencing at 34-35, United States v. Ridgill, No. 2:16cr-00631 (C.D. Cal. May 23, 2018) [hereinafter Reporter's Transcript, Ridgill].

105 Id. at 24. 
The court followed the Government's approach and counted only one year of prescriptions in calculating Dr. Ridgill's sentence. ${ }^{106}$ That yielded a guidelines range of 87 to 108 months. ${ }^{107}$ The Government argued for a sentence in the middle of that range: ninety-seven months. ${ }^{108}$

At sentencing, the judge expressed his disgust at Dr. Ridgill's claim that he was running a legitimate clinic:

Counsel, he is not operating a pain practice. He is operating a practice that allows people who abuse prescription medications to come to him to secure controlled substances that no other doctor who's reputable would be prescribing. . . . Cash basis -pretty much cash basis only. Money placed in patient files. Come on. The doctor hasn't learned -- one of the problems here that I see is this doctor has not learned his lesson. He is very brazen. He is very arrogant. ... He hasn't learned his lesson .... Look with all due respect to Dr. Ridgill, he is not a doctor. He has a license to practice, but he's not practicing medicine. ${ }^{109}$

Yet, without any real explanation, the court departed below the guidelines and imposed a sentence of sixty months. ${ }^{110}$

\section{Dr. Paul Ruble: Charged $\$ 200$ to $\$ 300$ per Prescription, Five} Years in Prison

Dr. Paul Spencer Ruble plead guilty in 2016 to federal charges of conspiracy to unlawfully dispense controlled substances and money laundering. ${ }^{111}$ Dr. Ruble, along with other conspirators, operated a pill mill for seventeen months. ${ }^{112}$ During that period, he wrote prescriptions for oxycodone, hydrocodone and other drugs without a medical purpose to "patients" who typically paid between $\$ 200$ and $\$ 300$ in cash for the prescriptions. ${ }^{113}$ During the seventeen months, there were more than 10,000 patient visits which amounted to "an average of 30 drug seeking patients ... per day." 114 The clinic brought in $\$ 2$ million,

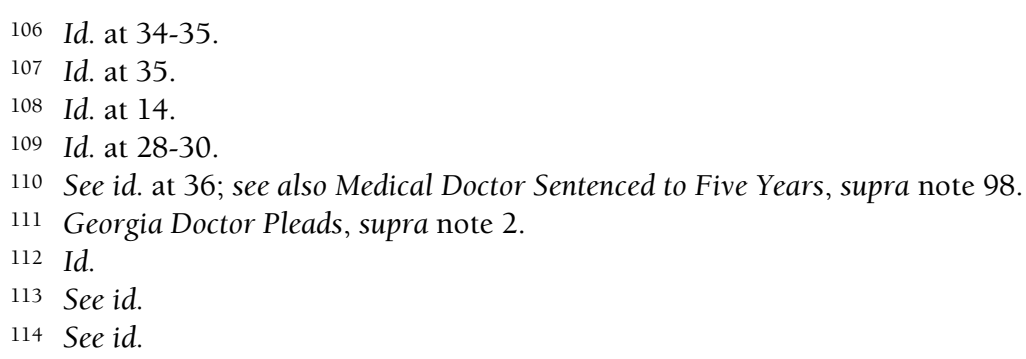


including \$1.7 million in cash, and Dr. Ruble was paid just under $\$ 500,000.115$

Although prosecutors originally indicted Dr. Ruble on one count of conspiracy and 442 counts of unlawfully dispensing a controlled substance, ${ }^{116}$ they agreed to a plea bargain that dropped all of the drug distribution charges and allowed Dr. Ruble to plead to only a general conspiracy charge. ${ }^{117}$ The general federal conspiracy statute carries a statutory maximum of five years in prison, ${ }^{118}$ and the court imposed the statutory maximum - sixty months - on Dr. Ruble. ${ }^{119}$

In a press release following sentencing, the United States Attorney claimed that Dr. Ruble ran "a phony pain management clinic" and "was another drug dealer that just happened to wear a white coat." 120 Yet, prosecutors agreed to drop all the drug-dealing charges that might have given rise to a longer penalty range.

8. Andrew Sun: 24,000 Prescriptions, \$1 Million in Illegal Profits, 5 1/4 Years in Prison

A jury convicted Dr. Andrew Sun of fourteen counts of illegally distributing opioids, as well as three counts of money laundering. ${ }^{121}$ Over a three-year period, Dr. Sun wrote 24,000 prescriptions and nearly $90 \%$ of those prescriptions were for hydrocodone (commonly known as Vicodin) and alprazolam (known as Xanax). ${ }^{122}$ When taken together, especially with cough syrup, these drugs form a potent cocktail sought

115 Georgia Doctor Sentenced to Federal Prison in Pill Mill Case, U.S. DeP’T JusT. U.S. AtTORnEY's OfF. S. District GA. (Apr. 4, 2017), https://www.justice.gov/usaosdga/pr/georgia-doctor-sentenced-federal-prison-pill-mill-case [https://perma.cc/8JVAGC6A] [hereinafter Georgia Doctor Sentenced].

116 See Indictment at 5-31, United States v. Ruble, No. 2:15-cr-00023 (S.D. Ga. Sept. 2, 2015).

117 See Plea Agreement at 1, 4, United States v. Ruble, No. 2:16-cr-00022 (S.D. Ga. Aug. 22, 2016).

118 See id. at 5. Unlike other pill mill doctors, Dr. Ruble was convicted under the general conspiracy statutes, 18 U.S.C. $\$ 371$, which carries a five-year maximum sentence. 18 U.S.C. \& 371 (2018). By contrast, the drug conspiracy statute, 21 U.S.C. \& 846 , carries the same penalties as the target drug offenses and thus can result in a punishment of up to 20 years for a single count. 21 U.S.C. $\$ 846$ (2018) (referring to penalties listed in 21 U.S.C. \& 841(b)(1)(C) (2018)).

119 See Georgia Doctor Pleads, supra note 2; Georgia Doctor Sentenced, supra note 115.

120 Georgia Doctor Sentenced, supra note 115.

121 See Government's Sentencing Position for Defendant Andrew Sun at 7, United States v. Sun, No. 2:14-cr-00157 (C.D. Cal. Nov. 7, 2014).

122 Id. at 8. 
after by those addicted to opioids. ${ }^{123}$ Medical experts testified that there is no legitimate medical purpose to prescribe Vicodin and Xanax together. ${ }^{124}$ Dr. Sun received more than $\$ 1$ million in cash in exchange for the prescriptions. ${ }^{125}$

Undercover agents testified that Dr. Sun sold them controlled substances twelve times over a nine-month period. ${ }^{126}$ In each case, Dr. Sun exchanged the drugs for $\$ 150$ in cash. ${ }^{127}$ To cover up his misconduct, Dr. Sun would suggest symptoms to patients and falsify medical records. ${ }^{128}$

Informants confirmed that Dr. Sun conspired with street dealers to bring in groups of fake patients in order to prescribe them pills. ${ }^{129}$ Two doctors retained by the Government as medical experts both testified that Dr. Sun was simply "acting as a prescription drug dealer, not a physician attempting to diagnose and treat illness."130

Nor was this Dr. Sun's first episode of misprescribing Vicodin and Xanax. Almost a decade earlier, the state medical board suspended his license after he was caught selling those drugs to an undercover officer in exchange for cash. ${ }^{131}$

At sentencing, the Government took the conservative position that only half of Dr. Sun's prescriptions were illegal, as well as the conservative position that each prescription contained only sixty pills. Accordingly, the prosecution estimated that Dr. Sun had put over 700,000 pills on the street. ${ }^{132}$ Because there was evidence that Dr. Sun had written twice as many prescriptions and that each prescription had contained 100 to 120 pills, the total quantity of drugs distributed by Dr. Sun was likely much higher, perhaps over 2.5 million pills. ${ }^{133}$

The guidelines range for Dr. Sun was sixty-three to seventy-eight months, but the Government sought a much longer sentence of 235

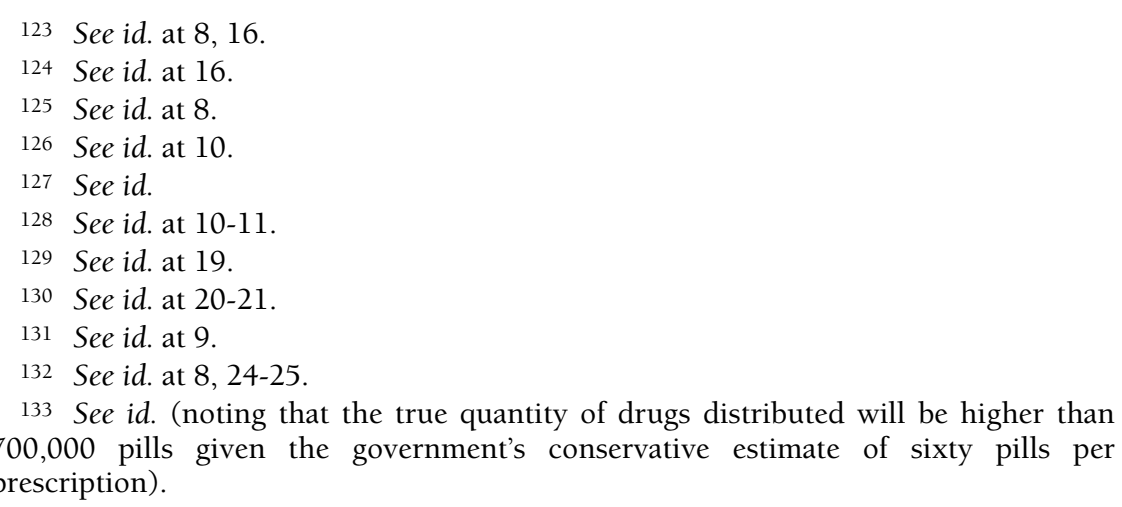


months. ${ }^{134}$ With no real discussion of the rationale, the court imposed a sentence of sixty-three months, the bottom of the guidelines range. ${ }^{135}$ It is of course possible that the judge was influenced by Dr. Sun's age he was seventy-nine years old. 136

9. Dr. Rodney Moret: Over One Million Pills, Drug Dealers Sold Pills in His Parking Lot, Six Years in Prison

Dr. Rodney Moret plead guilty to one count of conspiracy to illegally distribute prescription drugs and one count of conspiracy to commit health care fraud. ${ }^{137}$ Dr. Moret was the sole doctor at a medical clinic in Michigan that purported to be a pain management and HIV infusion clinic, but which the Justice Department said was "nothing more than a "pill mill."' 138 Dr. Moret prescribed opioids to fake patients and billed Medicare for examinations and tests that were never conducted. ${ }^{139}$ The fake patients then sold the drugs on the street. ${ }^{140}$ The pain clinic operated from 2010 until 2015 and Dr. Moret was responsible

for illegally distributing over 700,000 dosage units of Hydrocodone, (Vicodin, loratab), more than 240,000 dosage units of Alprazolam, and more than 2 million milliliters of promethazine with codeine cough syrup, worth more than $\$ 15$ million on the street market. He was responsible for over $\$ 6$ million in health care fraud. ${ }^{141}$

Federal officials claimed that his medical practice "resembled a drug house, where addicts drive up and exchange cash for pills in the parking

134 See Transcript of Sentencing at 5, 7-8, United States v. Sun, No. 2:14-cr-00157 (C.D. Cal. Mar. 27, 2015).

135 See id. at 6, 8.

136 See SoCal Doctor Who Distributed Addictive Painkiller Hydrocodone and Laundered More than \$1 Million in Illegal Proceeds Sentenced to Over Five Years in Federal Prison, U.S. Dep't Just. U.S. Attorney's Off. Central District Cal. (Jan. 5, 2015), https://www.justice.gov/usao-cdca/pr/socal-doctor-who-distributed-addictivepainkiller-hydrocodone-and-laundered-more-1 [https://perma.cc/EMA9-8ATW].

137 Former Doctor Sentenced to 75 Months in Prison for Illegally Prescribing Opiates and Committing Health Care Fraud, U.S. DeP'T Just. U.S. Attorney's OfF. E. District Mich. (Feb. 6, 2018), https://www.justice.gov/usao-edmi/pr/former-doctor-sentenced-75months-prison-illegally-prescribing-opiates-and-committing [https://perma.cc/EFD5HGN3] [hereinafter Former Doctor Sentenced to 75 Months].

138 Id.

139 See id.

140 See id.

141 Id. 
lot." 142 According to a medical expert retained by the Government, there was

no legitimacy to any aspect of defendant's practice ... [Dr. Moret] was constantly prescribing the highest doses (with the most street value) of narcotics ... ordered nearly identical tests for every patient, had over 13,000 [cash] prescriptions . . . [and] prescribed narcotics for up to five different people at the same address. ${ }^{143}$

Drug dealers were selling pills in the parking lot of Dr. Moret's clinic every day. ${ }^{144}$

Dr. Moret allegedly made more than $\$ 3$ million writing fake prescriptions. ${ }^{145}$ To make matters worse, Dr. Moret had previously worked as an addiction specialist before flooding the streets with addictive opioids. ${ }^{146}$ Finally, Dr. Moret was also accused of sexually fondling addicted patients. ${ }^{147}$ One patient reported him to local police and he plead no contest to criminal sexual conduct and received probation in state court prior to his federal sentencing. ${ }^{148}$

Dr. Moret plead guilty and his agreement with the Government called for a sentence of 97 to 121 months. ${ }^{149}$ The government vigorously argued for a 121-month sentence. ${ }^{150}$ The judge sentenced Dr. Moret who was sixty-seven years old at the time of sentencing - to a belowGuidelines sentence of seventy-five months. ${ }^{151}$ Dr. Moret will thus be released in his early seventies, rather than his late seventies as the Government had requested.

\footnotetext{
142 Kevin Dietz, Oakland County Doctor Accused of Sexually Abusing Addicted Patients Desperate for Prescription Pills, ClickonDetroit (Jan. 23, 2018, 11:28 PM), https://www.clickondetroit.com/news/2018/01/24/oakland-county-doctor-accused-ofsexually-abusing-addicted-patients-desperate-for-prescription-pills/ [https://perma.cc/ 94S5-JL2U].

143 Government's Second Memorandum, Moret, supra note 2, at 4-5.

144 See id. at 5.

145 See Dietz, supra note 142.

146 See id.

147 See id.

148 See Government's Sentencing Memorandum at 3, United States v. Moret, No. 2:15-cr-20723 (E.D. Mich. Oct. 17, 2017) [hereinafter Government's Sentencing Memorandum, Moret].

149 See id. at 4.

150 See id. at 4-5.

151 See Former Doctor Sentenced to 75 Months, supra note 137.
} 
10. Dr. Michael Minas: $\$ 100$ per Appointment, Easy Refills, High Dosages, Eight Years in Prison

Dr. Michael Minas was convicted on eighty counts of distributing controlled substances without a legitimate medical purpose (and acquitted on another fifty-nine counts). ${ }^{152}$ At trial, the Government introduced evidence that Dr. Minas had admitted knowing that $40 \%$ to $50 \%$ of his patients were drug seekers, as well as testimony that Dr. Minas was told six to eight times that his patients were selling their drugs. ${ }^{153}$ During the two-week trial, the jury heard evidence that Dr. Minas wrote prescriptions for "extraordinary" doses, such as 420 oxycodone pills of $30 \mathrm{mg}$ each. ${ }^{154}$ The evidence also showed that Dr. Minas generally charged $\$ 100$ cash for an appointment. ${ }^{155}$ Dr. Minas was cognizant he was engaged in illegal activity, once asking a patient if they were wearing a wire. ${ }^{156}$ During the sentencing hearing, the prosecutor noted that Dr. Minas "went from a doctor beloved by patients - because he spent ample time to get at the root of their problems - to someone who took in new patients that were so sketchy even his office workers knew they were coming in just for a prescription fix." 157 The prosecutor added that Dr. Minas "would accept any excuse in the book to hand out a new 30-day prescription 10 or 20 days after issuing the last one." 158

Given the large drug quantity, Dr. Minas faced a guidelines range of 151 to 188 months. 159 The Government recommended a sentence in the middle of the range - 160 months. ${ }^{160}$ The judge rejected the guidelines range and the Government's recommendation, mentioning that such a long sentence "would create an undue expense on society when you are not a threat to society and when you have given up or lost your license

152 See Boise Doctor Convicted of Controlled Substances Delivery, U.S. DEP'T JUST. U.S. AtTORney's OFF. District IDAHO (Sept. 8, 2016), https://www.justice.gov/usao$\mathrm{id} /$ pr/boise-doctor-convicted-controlled-substance-delivery [https://perma.cc/3RQQQYTX] [hereinafter Boise Doctor Convicted].

153 Government's Answering Brief at 15, United States v. Minas, 697 F. App'x 531 (9th Cir. 2017) (No. 16-30209).

154 Boise Doctor Convicted, supra note 152.

155 See id.

156 See Transcript of Sentencing Hearing at 30-31, United States v. Minas, No. 1:14cr-00109 (D. Idaho Oct. 31, 2016) [hereinafter Transcript of Sentencing, Minas].

157 See John Sowell, Financial Woes Set Eagle Doctor on the Road to Prison, IDAHO STATESMAN (Sept. 8, 2016, 2:05 PM), https://www.idahostatesman.com/news/local/ crime/article100673232.html [https://perma.cc/B487-9C35].

158 See id.

159 See Transcript of Sentencing, Minas, supra note 156, at 4, 18.

160 See id. at 33-34 
to practice medicine."161 The judge accordingly imposed a sentence of ninety-six months in prison. ${ }^{162}$

\section{Dr. Zongli Chang, 2.7 Million Pills, Fraudulent Medicare Billing, Eleven Years in Prison}

Dr. Zongli Chang plead guilty to running a massive pill mill operation in Michigan between 2012 and 2017. Dr. Chang conspired with "patient recruiters" to bring fake patients into the office and write them unnecessary prescriptions.163 Dr. Chang conducted little or no examinations, but nevertheless billed Medicare and Medicaid for the patient visits. ${ }^{164}$ Eventually, he was banned from Medicare reimbursement, and instead required patients to pay between $\$ 150$ and $\$ 400$ in cash, depending on how desirable the drug was. ${ }^{165}$ After Dr. Chang wrote the opioid prescriptions, the recruiters would transport the fake patients to pharmacies to fill the prescriptions and then the recruiters would take possession of the drugs in order to sell them on the street. ${ }^{166} \mathrm{Dr}$. Chang wrote prescriptions for more than 2.7 million dosage units, which put $\$ 18$ million in controlled substances on the street. ${ }^{167}$

Federal prosecutors initially charged Dr. Chang with one count of conspiracy, thirty-nine counts of distributing a controlled substance, and three counts of health care fraud. ${ }^{168}$ They agreed, however, to allow him to plead guilty only to the conspiracy charge. ${ }^{169}$ As part of the plea agreement, the parties agreed on a guidelines range of 108 to 135 months, which they reached by counting 161,280 units of Schedule II drugs and 158,164 units of Schedule IV controlled substances. ${ }^{170}$ These amounts were far below the total amount of drugs that Dr. Chang

161 See id. at 48.

162 Id. at 49.

163 See Government's Sentencing Memorandum at 2-3, United States v. Chang, No. 2:18-cr-20008 (E.D. Mich. Mar. 20, 2019) [hereinafter Government's Sentencing Memorandum, Chang].

164 See Transcript of Sentencing Hearing, Chang, supra note 2, at 26.

165 See id. at 26-27.

166 See id. at 27.

167 See Livonia Doctor, 7 Others Charged in \$18 Million Prescription Drug Scheme, Fox 2 Detroit (Jan. 9, 2018), https://www.fox2detroit.com/news/livonia-doctor-7-otherscharged-in-18m-prescription-drug-scheme [https://perma.cc/5TXE-85NQ].

168 See Indictment at 5-15, United States v. Chang, No. 2:18-cr-20008 (E.D. Mich. Jan. 4, 2018).

169 See Rule 11 Plea Agreement at 1-2, United States v. Chang, No. 2:18-cr-20008 (E.D. Mich. Nov. 20, 2018).

170 See Transcript of Sentencing Hearing, Chang, supra note 2, at 6, 27. 
illicitly prescribed. At sentencing, the government recommended a sentence of 120 months. ${ }^{171}$

The judge was struck not only by the breadth of the conspiracy and misconduct but also the amount of money Dr. Chang had in cash:

I almost fell out of my seat when the testimony developed regarding the amount of cash that was found in your home. . . I think it was over $\$ 600,000$ in cash in your house in boxes, in closets.... That's the type of cash that the DEA pulls out after [the] search for a major cocaine or heroin dealer."172

Based on the quantity of money and Dr. Chang's lack of remorse, ${ }^{173}$ the court sentenced Dr. Chang to 135 months in prison - the top of the guidelines range, and more than even the Government had requested. ${ }^{174}$

\section{Dr. Dwight Bailey: 14,000 Pills to One Patient, 12.5 Years in} Prison

After a two-week jury trial, Dr. Dwight Bailey was convicted of sixtyone counts of illegal drug distribution, including twenty-four counts of unlawfully distributing Schedule II controlled substances. ${ }^{175}$ Although prosecutors did not "charge the death" for sentencing purposes, the evidence at trial showed that five of Dr. Bailey's patients died from drug overdoses. ${ }^{176}$ Dr. Bailey prescribed one of those patients more than 14,000 oxycodone pills. ${ }^{177}$ Dr. Bailey and other providers in his office "continually wrote prescriptions for opiates, benzodiazepines, and sleeping pills to patients who were clearly misusing, abusing, and diverting those controlled substances."178 Dr. Bailey profited handsomely, earning more than $\$ 750,000$ in a single year. ${ }^{179}$

171 Government's Sentencing Memorandum, Chang, supra note 163, at 4.

172 See Transcript of Sentencing Hearing, Chang, supra note 2, at 29-30.

173 See id. at 36-37.

174 See id. at 32-33.

175 See Lebanon Doctor Sentenced on Federal Drug Distribution Charges, U.S. DeP'T Just. U.S. AtTORNEY's OfF. W. District VA. (Jan. 31, 2019), https://www.justice.gov/ usao-wdva/pr/lebanon-doctor-sentenced-federal-drug-distribution-charges [https://perma. cc/L66Q-WT74].

176 See Government's Motion for Sentencing Variance at 1-2, United States v. Bailey, No. 1:17-cr-00036 (W.D. Va. Jan. 31, 2019) [hereinafter Government's Motion, Bailey] For background on "charging the death," see supra note 12.

177 Lebanon Doctor Guilty of Illegal Distribution of Narcotics, WCYB (Aug. 1, 2018), https://wcyb.com/news/local/update-lebanon-doctor-guilty-of-illegal-distribution-ofnarcotics [https://perma.cc/FRC8-ZVAL].

178 Lebanon Doctor Sentenced on Federal Drug Distribution Charges, supra note 175.

179 See id. 
Worse yet, Dr. Bailey also ran a substance abuse treatment program as part of his practice. ${ }^{180}$ He was authorized to prescribe suboxone - a drug that is supposed to help patients addicted to opioids - as a medically assisted treatment. ${ }^{181}$ Yet, after enrolling these patients in a suboxone treatment program to help with their opioid addiction, Dr. Bailey continued to prescribe them opioids. ${ }^{182}$

The guidelines range called for a sentence between 151 and 188 months, but the government moved for a sentence variation and sought 240 months. ${ }^{183}$ The district judge imposed a sentence of 151 months. ${ }^{184}$

\section{Dr. Carlos Venegas: Over Two Million Pills, Paid Homeless} People to Act as Patients, Thirteen Years in Prison

A jury convicted Dr. Carlos Venegas of conspiracy to distribute a controlled substance. ${ }^{185}$ The evidence at trial showed that Dr. Venegas was the supervising physician for multiple sham medical clinics that illegally distributed hydrocodone and alprazolam. ${ }^{186}$ Those drugs create a dangerous cocktail sought after by opioid addicts. Dr. Venegas typically prescribed the highest doses available. ${ }^{187}$

Dr. Venegas conspired with others to pay homeless and poor individuals to pose as patients. ${ }^{188}$ Runners coached these "patients" on what symptoms to make up, then drove them to the clinics, and paid for their appointments. ${ }^{189}$ Dr. Venegas and his staff conducted virtually no examinations and medical records did not document any diagnostic testing. ${ }^{190}$

In total, prosecutors established that "over two million units of Hydrocodone ... were distributed by Doctor Venegas or by those who he was responsible for." 191 Because he was convicted of only one count, Dr. Venegas faced a maximum sentence of twenty years. ${ }^{192}$ The

\footnotetext{
180 See Government's Motion, Bailey, supra note 176, at 4 .

181 See id.

182 See id.

183 Id. at 1.

184 See Lebanon Doctor Sentenced on Federal Drug Distribution Charges, supra note 175.

185 Pill Mill Physician, supra note 5.

186 Id.

187 Id.

188 Id.

189 Id.

190 See id.

191 Transcript of Sentencing Hearing at 44, United States v. Venegas, No. 3:16-cr00479 (N.D. Tex. July 20, 2019) [hereinafter Transcript of Sentencing, Venegas].

192 See id. at 47.
} 
prosecution argued forcefully for the twenty-year sentence given that Dr. Venegas and the nurses he supervised had prescribed more than 2 million pills. ${ }^{193}$ The Government mentioned (but did not rely on) even more opioid prescriptions that were issued by other doctors while Dr. Venegas was the medical director of the clinic. ${ }^{194}$ The judge noted the seriousness of the offense, but did not want to incarcerate Dr. Venegas for the rest of his life, explaining that "I do think it should give the Doctor some hope of being free on the outside at the conclusion of the sentence." 195 Accordingly, based on Dr. Venegas age of sixty-two, the judge imposed 156 months, so that he would be "74-ish" when he gets out. 196

14. Dr. Daniel Cham: Prescriptions After Midnight, $\$ 200$ per Prescription, Thirteen Years in Prison

Dr. Daniel Cham plead guilty to one count of illegally distributing oxycodone and one count of money laundering. Although the Government's sentencing memorandum does not attempt to quantify the number of prescriptions Dr. Cham wrote, ${ }^{197}$ it is clear that he was issuing thousands of prescriptions each year, nearly all of which were for the same opioid drug combinations, and most of which were for the maximum doses. ${ }^{198}$ Surveillance footage from a pole camera outside of his office found that he "maintained work hours exclusively between 8 p.m. and 2 a.m. on Fridays and Saturdays and between noon and 2 p.m. on Sundays ...."199 Yet, in writing prescriptions he changed the dates to make it appear that he issued them during normal business hours. 200 On an undercover government agent's first visit, Dr. Cham met with the agent for only three minutes. ${ }^{201}$ Rather than first asking the agent about his medical problems or examining him, Dr. Cham immediately asked "You want medication? What medication do you want?"202 Shortly thereafter, Dr. Cham asked the agent "You got your money order?" and

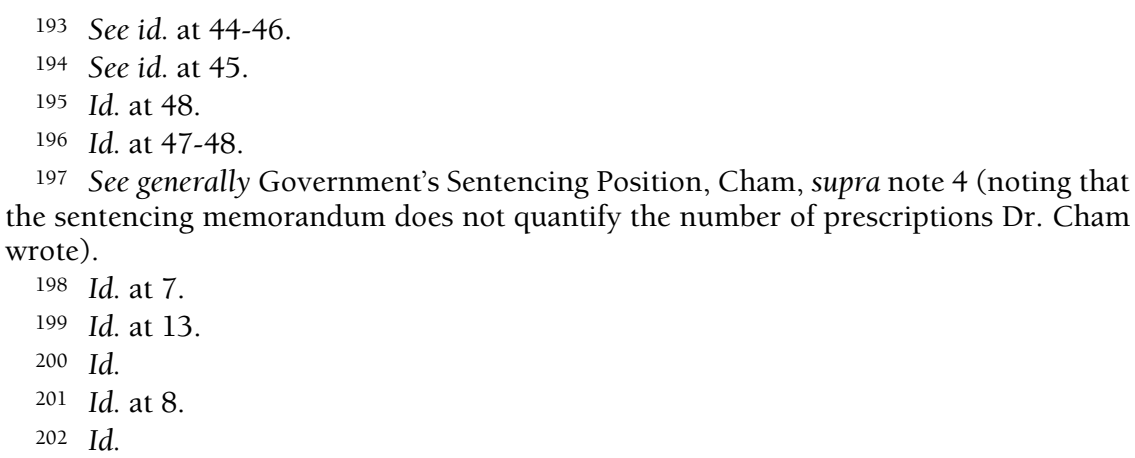


accepted $\$ 200$ in exchange for the prescription. ${ }^{203}$ In a subsequent visit, Dr. Cham told the agent that a prescription for oxycodone would be more money - $\$ 300$ - because that prescription is "more complicated." 204 According to a government investigator, $100 \%$ of the money Dr. Cham received from patients was in cash or money orders. ${ }^{205}$

The Government presented evidence that Dr. Cham even provided prescriptions to patients outside of his office. One patient testified at the sentencing hearing that Dr. Cham arranged to meet him at a Starbucks, where he exchanged cash for a prescription. 206

The Government also documented that Dr. Cham - a California physician - was involved in a conspiracy with Oregon drug traffickers and that Oregon pharmacy records showed more than 12,000 pills dispensed to a handful of co-conspirators. ${ }^{207}$ According to the prosecutor, a co-conspirator filled "prescriptions from Dr. Cham in over a dozen false aliases, non-existent persons. Dr. Cham was creating medical records for patients who didn't exist. He was postdating all of his prescriptions. He was laundering all of his funds. He was lying to every level of regulator and law enforcement officer." 208 Additionally, the Government also documented how two of Dr. Cham's patients died of prescription overdoses. ${ }^{209}$

Prosecutors requested a 210-month sentence based only on the prescriptions written to co-conspirators and the undercover agent.210 The prosecutor noted that "we are not looking beyond that set of prescriptions," even though the "relevant conduct goes to the entire scope of [Dr. Cham's] illicit practice."211 In other words, had the guidelines range been calculated by the entirety of the prescriptions Dr. Cham issued, rather than a far smaller selection to a handful of individuals, the sentencing range would have been markedly higher.

The judge set the guidelines range at 151 to 188 months and imposed a sentence of 160 months in prison. ${ }^{212}$

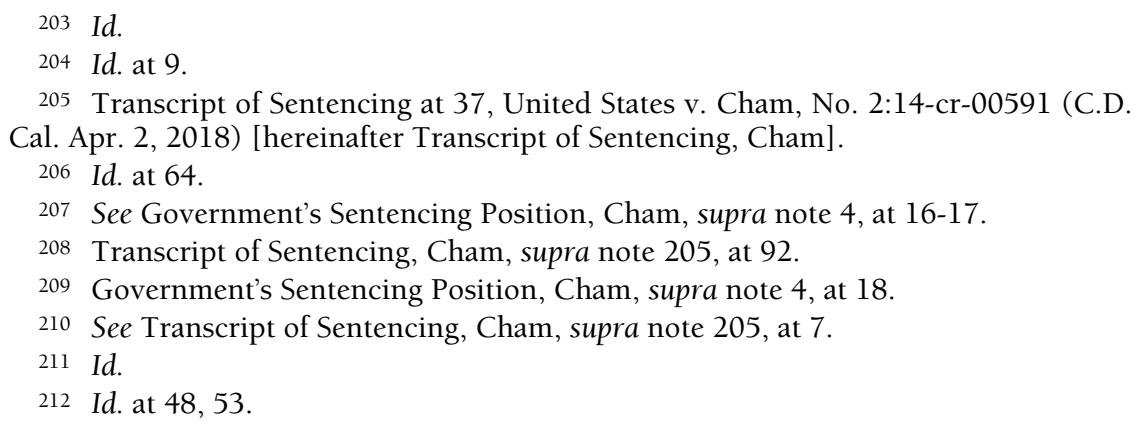


15. Dr. Moshe Mirilashvili: 1.2 Million Pills, Made $\$ 2$ Million, $131 \frac{1}{3}$ Years in Prison

According to a New York Times story, at dawn "packs of brawny men" who did not seem to be battling chronic pain lined up outside of Dr. Moshe Mirilashvili's office. ${ }^{213}$ These "patients" were "members of drug crews who were recruited and paid by traffickers to pose as patients in order to receive medically unnecessary prescriptions." 214 Dr. Mirilashvili charged them "\$200 in cash for patient visits that involved little actual care, but almost always led to his prescribing 90 30milligram tablets of oxycodone." 215 His office staff "created fake M.R.I. reports to suggest that patients were injured, and also manufactured urinalysis reports to certify that the patients were taking, rather than selling, the oxycodone ...."216 The Government presented evidence of "stacks of purported medical documents recovered from the defendant's home in which names of patients had been visibly whited out or even taped onto an existing document."217 Based on a review of patient files, a medical expert presented by the Government concluded that Dr. Mirilashvili's office "wasn't a medical practice."218

Over a two-year period, Dr. Mirilashvili allegedly wrote more than 13,000 medically unnecessary oxycodone prescriptions, amounting to 1.2 million pills. ${ }^{219}$ Dr. Mirilashvili collected more than $\$ 2$ million in cash fees.220 The Government presented evidence that the majority of Dr. Mirilashvili's patients paid cash and handed the money directly to him in the treatment room. 221

213 Benjamin Mueller, U.S. Arrests Manhattan Doctor in Oxycodone Ring, N.Y. TIMES (Dec. 11, 2014), https://www.nytimes.com/2014/12/12/nyregion/us-arrests-manhattandoctor-in-oxycodone-ring.html [https://perma.cc/9R8S-GH6U].

214 Id.

215 Id.

216 Id.

217 Sentencing Memorandum of the United States at 5-6, United States v. Mirilashvili, No 1:14-cr-00810 (S.D.N.Y. Sept. 21, 2016) [hereinafter Sentencing Memorandum, Mirilashvili].

218 Id. at 8.

219 See Mueller, supra note 213.

220 New York Doctor Sentenced to More than 13 Years in Prison for Unlawfully Dispensing Nearly 1 Million Oxycodone Pills, U.S. DeP'T Just. U.S. AtTORneY's OfF. S. DisTRICT N.Y. (Sept. 28, 2016), https://www.justice.gov/usao-sdny/pr/new-york-doctorsentenced-more-13-years-prison-unlawfully-dispensing-nearly-1-million [https://perma. $\mathrm{cc} / \mathrm{YH} 8 \mathrm{U}-\mathrm{S} 7 \mathrm{VJ}]$.

221 Sentencing Memorandum, Mirilashvili, supra note 217, at 6. 
At trial, a jury convicted Dr. Mirilashvili of one count of conspiracy to distribute oxycodone and two counts of distributing oxycodone.222

Because of the huge number of pills involved, Dr. Mirilashvili faced a guidelines range of 292 to 365 months in prison. ${ }^{223}$ The probation office recommended a sentence at the bottom of that range. ${ }^{224}$ Dr. Mirilashvili's lawyers argued for a lower drug quantity and therefore a lower sentencing range of 151 to 188 months. ${ }^{225}$

At sentencing, Dr. Mirilashvili's lawyer focused at length on his age - sixty-eight - and how older prisoners are more expensive to incarcerate. ${ }^{226}$ When Dr. Mirilashvili had a chance to speak at the sentencing hearing, he also noted his age and that he was an "old man."227 The court showed little sympathy for that argument though:

Your very fine lawyer says most eloquently that I should not sentence you to a lifetime of imprisonment. He says that you are an old man .... To which I say if you commit a crime on the scale of your narcotics operation when you're in your mid-60s then you have to do your punishment while you are old. You are no less deserving of punishment because you were old when you [] engaged in this nefarious behavior. ${ }^{228}$

When it came time to compute the drug quantity and determine the appropriate guidelines range, the court recognized that the Government was correct about the drug quantity and the guideline calculation, but the judge felt that level of sentence was too high. ${ }^{229}$ The judge accordingly - and seemingly without legal basis - adopted a guidelines range of 151 to 188 months as requested by the defense. 230 The court then imposed a sentence within the guidelines range of 160 months. ${ }^{231}$

222 United States v. Leonard, 738 F. App'x 7, 8 (2d Cir. 2018).

223 Sentencing Memorandum, Mirilashvili, supra note 217, at 11.

224 See id.

225 See Transcript of Sentencing at 8-11, United States v. Mirilashvili, No. 1:14-cr00810 (S.D.N.Y. Oct. 13, 2016) [hereinafter Transcript of Sentencing, Mirilashvili].

226 See id. at 11-16, 24.

227 Id. at $28,31$.

228 Id. at 37.

229 Id. at 32 ("While I agree with the government that the jury's verdict would allow me to find the drug quantity that the government submits is correct, I do not need to drive the guideline sentence up to a level of 292 months . . . I'm not going to sentence Dr. Mirilashvili to 292 months, no intention of sentencing him to 292 months . . ..").

230 See id.

231 Id. at 40. 
16. Dr. Christopher Stegawski: Broke into His Clinic After Police Had Closed It and Continued to Prescribe Pills, 13 1/3 Years in Prison

Dr. Chistopher Stegawski moved to Southern Ohio specifically to operate a pill mill.232 Evidence at trial demonstrated that Dr. Stegawaski saw up to forty patients a day. ${ }^{233}$ Some of these patients "traveled in excess of 200 miles roundtrip to obtain prescriptions ...."234 He "knowingly prescribed" large numbers of pills to drug abusers in exchange for $\$ 200$ in cash per visit. 235 Dr. Stegawaski performed little or no physical examinations. ${ }^{236}$ Multiple local pharmacies refused to fill his prescriptions on the ground that he was prescribing drugs to those who were addicted. ${ }^{237}$ The evidence also indicated that Dr. Stegawski exchanged pills for sex. 238

Dr. Stegawski and his partner closed their first clinic when law enforcement began investigating them. ${ }^{239}$ They then set up a new pill mill in a different location.240 After a disagreement with his business partner, Dr. Stegawski tried to open a new clinic in a third location, but the police shut it down. ${ }^{241}$ His brazenness did not end there:

With the help of some opioid-addicted patients, the doctor broke into [his shuttered] clinic with bolt cutters. He then resumed his practice there until law enforcement (again) closed the clinic. Stegawski and one of his female patients opened yet another clinic in nearby South Point, Ohio. Before long, law enforcement closed that clinic also. 242

A jury convicted Dr. Stegawski on one count of conspiracy to distribute prescription drugs, one count of conspiracy to launder money and two counts of maintaining a place for illegal distribution of drugs. ${ }^{243}$ At sentencing, the guidelines range was 293 to 365 months, subject to a

\footnotetext{
232 Transcript of Proceedings, Stegawski, supra note 6, at 40.

233 'Pill Mill' Operators, supra note 5.

234 Id.

235 Id.

236 Id.

237 Id.

238 Transcript of Proceedings, Stegawski, supra note 6, at 39.

239 See United States v. Stegawski, 687 F. App'x 509, 511 (6th Cir. 2017).

240 Id.

241 Id.

242 Id.

243 'Pill Mill' Operators, supra note 5.
} 
statutory maximum of 240 months. ${ }^{244}$ The probation office recommended 240 months, as did the prosecutor. ${ }^{245}$ The court, in part based on Dr. Stegawski's age, imposed a sentence of 160 months. ${ }^{246}$

17. Dr. Shelinder Aggarwal: 12.3 Million Pills, 423 Prescriptions per Day, Heath Care Fraud, Fifteen Years in Prison

Dr. Shelinder Aggarwal ran one of the nation's largest and most egregious pill mills in Huntsville, Alabama. Dr. Aggarwal prescribed a staggering number of pills. "In 2012, about 80 to 145 patients a day visited Aggarwal's clinic, with him seeing the majority of patients ... ."247 In that same year, Alabama pharmacies filled about 110,013 of Aggarwal's prescriptions for controlled substances, which would amount to "423 prescriptions per day if he worked five days a week" the equivalent of 12.3 million pills. ${ }^{248}$ Dr. Aggarwal was the highest prescriber of controlled substances in Alabama in 2012, with the next highest prescriber writing a third as many prescriptions. ${ }^{249}$ Indeed, Dr. Aggarwal was the highest single prescriber of Schedule II controlled substances (which includes many opioids) for Medicare in the entire country in 2012. 250

According to prosecutors, Dr. Aggarwal

documented examinations that he did not conduct; did not obtain or review patients' medical records; did not attempt to treat patients with anything other than controlled substances; did not order testing other than urine drug tests (the results of which he routinely ignored); and wrote prescriptions simply based on what the patient requested. ${ }^{251}$

Moreover, Dr. Aggarwal prescribed opioids to patients even if they failed urine tests for illegal drugs and even if the patients admitted they

\footnotetext{
244 Transcript of Proceedings, Stegawski, supra note 6, at 6, 31.

245 See id. at $31,41$.

246 Id. at 43-44.

247 Huntsville Pill Mill Doctor Sentenced to 15 Years in Prison for Illegal Prescribing and Health Care Fraud, U.S. DeP'T Just. U.S. Attorney's OfF. N. District Ala. (Feb. 7, 2017), https://www.justice.gov/usao-ndal/pr/huntsville-pill-mill-doctor-sentenced-15-yearsprison-illegal-prescribing-and-health [https://perma.cc/F9YY-HCBN] [hereinafter Huntsville Pill Mill Doctor Sentenced].

248 Id.

249 Id.

250 Id.

251 Government's Sentencing Memorandum at 4-5, United States v. Aggarwal, No. 5:16-cr-00299 (N.D. Ala. Feb. 1, 2017).
} 
were using illegal drugs. ${ }^{252}$ At the same time that he failed to even review the urine tests, Dr. Aggarwal billed Medicare for those tests. ${ }^{253}$

Federal prosecutors entered into a binding plea deal with Dr. Aggarwal in 2016 in which he plead guilty to illegal drug dealing and health care fraud and agreed to a fifteen-year sentence. ${ }^{254}$ The judge followed the plea agreement and imposed a sentence of fifteen years. 255 Dr. Aggrawal's case appears to be one of the most egregious. It therefore makes sense that he would receive a lengthy sentence of fifteen years. Yet, each of the eight pill mill cases discussed in the pages that follow involved smaller quantities of drugs but ended with longer sometimes much longer — sentences.

18. Dr. Rafael Beier: Sold Prescriptions for $\$ 800$ each, Traded Sex for Drugs, Sixteen Years in Prison

Dr. Beier was charged with conspiracy to distribute controlled substances and more than sixty counts of illegally distributing controlled substances. ${ }^{256}$ The jury convicted him of all counts. ${ }^{257}$ The evidence at trial showed that Dr. Beier "sold prescriptions for highly addictive drugs like oxycodone, Adderall and hydrocodone in exchange for cash at locations such as bars, parking lots, stores, as well as his office." 258 Dr. Beier would sell ninety oxycodone pills in exchange for $\$ 800$ to erotic dancers, who in turn sold each pill for between $\$ 20$ and $\$ 40 .{ }^{259} \mathrm{He}$ communicated with the dancers with prepaid cell phones what drug dealers call burner phones - to avoid detection. ${ }^{260}$

The jury heard evidence that Dr. Beier created false medical charts to cover up illegal drug sales and an audio recording of an informant

252 Id. at 5.

253 See id. at 6-7.

254 Huntsville Pill Mill Doctor Sentenced, supra note 247.

255 Id.

256 Transcript of Sentencing Hearing at 4, United States v. Beier, No. 2:14-cr-00117 (D. Idaho Jan. 23, 2018) [hereinafter Sentencing Hearing, Beier].

257 See id.

258 Doctor Sentenced to 16 Years for Distributing Drugs, U.S. DEP'T JUST. U.S. ATTORNEY's OFF. DiSTRICT IDAHO (Nov. 30, 2017), https://www.justice.gov/usao$\mathrm{id} / \mathrm{pr} /$ doctor-sentenced-16-years-distributing-drugs [https://perma.cc/DW47-MGLV] [hereinafter Doctor Sentenced to 16 Years].

259 Jake Thomas, An Idaho Doctor Turns Drug Dealer, BoISE WkLy. (Sept. 14, 2016), https://www.idahopress.com/boiseweekly/news/features/an-idaho-doctor-turns-drugdealer/article_065fa780-0b9c-592a-ad2e-ebcb59fddf54.html [https://perma.cc/B6KDPJ3V].

260 See id. 
buying a prescription from Dr. Beier in a bathroom stall. ${ }^{261}$ The testimony at trial included co-conspirators who sold pills for Dr. Beier, as well as non-patients whose names Dr. Beier used to write illegal prescriptions. ${ }^{262}$ There was also evidence that Dr. Beier exchanged pills for sex. ${ }^{263}$

Dr. Beier perpetrated some of his drug distribution schemes by having co-conspirators bring him names and personal information so that he could use their identities to write fake prescriptions. When it came time for sentencing, the prosecution did not attempt to rely on all of the prescriptions because there were so many that co-conspirators "couldn't recall all of the fake names they used." 264 In calculating the drug weight, the court erred on the side of caution and did not include seemingly illegal prescriptions that were outside the time window of the known conspiracy. ${ }^{265}$ Based on these conservative steps, the court reached a guidelines range of 188 to 235 months. 266 The court imposed a sentence of 192 months, or sixteen years. ${ }^{267}$ Given that Dr. Beier was sixty-three years old at sentencing, ${ }^{268}$ he will be incarcerated until his late seventies.

19. Donovan Dixon: Conspired with Street Dealers to Use Fake Patients Names to Write Prescriptions, Twenty Years in Prison

Dr. Donovan Dixon was convicted by a jury of conspiracy to distribute oxycodone and twenty counts of distributing oxycodone outside the course of professional practice. ${ }^{269}$ The DEA discovered Dr. Dixon's misconduct when they realized that four of the top ten pharmacies in the state for oxycodone prescriptions operated near his practice. 270 Dr. Dixon prescribed high-strength and high-dosage amounts of oxycodone with little or no medical examination. ${ }^{271}$

\footnotetext{
261 Doctor Sentenced to 16 Years, supra note 258.

262 See id.

263 Government's Sentencing Memorandum at 6, United States v. Beier, No. 2:14-cr00117 (D. Idaho Nov. 21, 2017).

264 See Sentencing Hearing, Beier, supra note 256, at 19.

265 See id. at 10, 24.

266 See id. at 25.

267 Id. at 49.

268 Doctor Sentenced to 16 Years, supra note 258.

269 Pembroke Medical Doctor Sentenced to 20 Years for Unlawfully Distributing Oxycodone, U.S. DeP't Just. U.S. AtTORney's OfF. E. District N.C. (Aug. 27, 2018), https://www.justice.gov/usao-ednc/pr/pembroke-medical-doctor-sentenced-20-yearsunlawfully-distributing-oxycodone [https://perma.cc/7AVL-PXY7].

270 Id.

271 Id.
} 
Multiple witnesses testified at trial that they had never met Dr. Dixon even though hundreds of prescriptions had been issued in their names. ${ }^{272} \mathrm{~A}$ street dealer testified that he provided Dr. Dixon with the names of "patients" and that Dr. Dixon would write oxycodone prescriptions in exchange for cash. ${ }^{273}$ Those prescriptions were later sold on the street. ${ }^{274}$ Additional testimony indicated that Dr. Dixon met a conspirator in a parking lot and wrote prescriptions for the conspirator's wife, parents, cousin, and cousin's girlfriend. ${ }^{275}$ Dr. Dixon clearly knew these prescriptions would be sold on the street. 276

Based on a large drug quantity, the court calculated a guidelines range of 235 to 293 months. ${ }^{277}$ The government advocated for a sentence close to the top of the range - 288 months. ${ }^{278}$ The court considered Dr. Dixon's prior military service and his health issues, but refused to depart below the guidelines range and imposed a sentence of 240 months. ${ }^{279}$

20. Dr. Tad Taylor: 12,000 Prescriptions, No Examinations, Twenty Years in Prison

A jury convicted Dr. Tad Taylor of conspiring to distribute oxycodone and multiple other opioids. During the conspiracy, Dr. Taylor wrote nearly 12,000 prescriptions, which likely resulted in up to one million pills being issued. 280 According to an undercover investigator who got pills from the clinic, "they're handing out these prescriptions like candy." 281 Undercover video showed Dr. Taylor conducted no real medical examinations and simply waited for the patients to say

272 Id.

273 Id.

274 Id.

275 Transcript of Sentencing Hearing at 40, United States v. Dixon, No. 7:16-cr00030 (E.D.N.C. Feb. 11, 2019).

276 See id.

277 Id. at 35-36.

278 Id. at 42.

279 Id. at 47-49.

280 See Tanya Eiserer, "They're Handing Out These Prescriptions Like Candy": Undercover DEA Video Shows Pill Mill in Action, WFAA (Sept. 27, 2019, 9:29 PM CDT), https://www.wfaa.com/article/news/local/investigates/undercoverdeapillmillvideo/2871373c2f9-4149-40e9-8ebe-2f3fedelc549 [https://perma.cc/52P9-Y37Q] (discussing a case where a doctor prescribed a monthly maximum of ninety pills - 12,000 of these prescriptions would likely total over one million pills); Will Maddox, Drug-Trafficking Couple Who Owned Richardson Clinics Convicted, Dall. MAG. (Oct. 17, 2018, 9:32 AM), https://www.dmagazine.com/healthcare-business/2018/10/drug-trafficking-couplewho-owned-richardson-clinics-convicted/ [https://perma.cc/TY48-F2V4].

281 Eiserer, supra note 280. 
something that he could write down in the file that could possibly justify a prescription. ${ }^{282}$ The videos also show Dr. Taylor ignoring urine tests that indicated the patients were selling, rather than personally taking, the drugs. ${ }^{283}$ According to a former patient, "Dr. Taylor will give you anything you want." 284

The drug quantity gave rise to an advisory guidelines sentence of 240 months. ${ }^{285}$ At sentencing, the prosecution explained that the quantity of drugs they had attributed to Dr. Taylor was actually low because the government did not count the drugs prescribed in the last four months of the conspiracy and "[o]n top of that ... we took an across-the-board reduction of 25 percent of all drug quantities giving the benefit of the doubt to the extreme ... that somehow, somewhere mixed in with their patient base there were some limited number of legitimate prescriptions." 286 The court agreed that the government had been more generous than necessary in computing the drug calculation. ${ }^{287}$ Furthermore, the defendant surely harmed himself at sentencing by refusing to show any contrition and by making baseless accusations that the prosecutors were corrupt and had lied in court. ${ }^{288}$ Dr. Taylor's lawyer attempted to argue that his advanced age of sixty-five meant any lengthy sentence would be a death sentence, ${ }^{289}$ but the court was unmoved and imposed a sentence of 240 months. ${ }^{290}$

21. \& 22. Dr. John Couch and Dr. Xiulu Ruan: Kickbacks, Illegitimate Pharmacy, Twenty and Twenty-One Years in Prison

Dr. John Couch and Dr. Xiulu Ruan operated a pain clinic together in Alabama. The indictment alleged that they wrote almost 67,000 prescriptions for painkillers in just one year - an average of one prescription every four minutes. ${ }^{291}$ Many of the prescriptions were for opioid sprays - Subsys and Abstral — which the doctors wrote for neck and back pain, even though those drugs were approved only for cancer

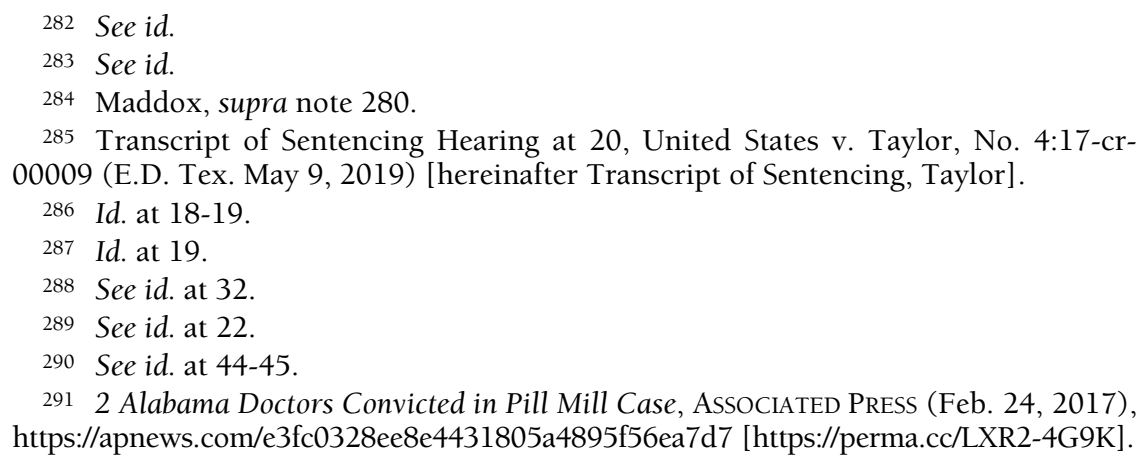


pain.292 Both doctors allegedly received kickbacks from the manufacturer of Subsys in exchange for writing prescriptions. ${ }^{293}$ The doctors also bought $\$ 1.6$ million in stock from the company that made Abstral and wrote prescriptions in an effort to manipulate the stock price. ${ }^{294}$ Drs. Couch and Ruan were the number one and two prescribers of Abstral in the country, writing one-third of the nation's prescriptions for that drug. ${ }^{295}$ Both doctors also prescribed morphine, oxycodone, methadone, hydromorphone, oxymorphone, and fentanyl. ${ }^{296}$

To maximize their profits, Drs. Couch and Ruan took the almost unheard of step of opening their own pharmacy (C\&R Pharmacy) that would fill only their own prescriptions. ${ }^{297}$ "Approximately $91 \%$ of the Subsys and Abstral prescriptions written by the defendants - which cost patients' insurance anywhere between $\$ 1,000.00$ to $\$ 24,000.00$ per month - were filled at C\&R Pharmacy." 298 At trial, the Government presented evidence that Dr. Couch "rarely saw patients during followup visits" and that prescriptions were written in his name by someone without authority to do so. ${ }^{299}$ The government pointed to more than 5,000 prescriptions for Schedule II drugs that were written in Dr. Couch's name when he was out of the state or country. 300

Drs. Couch and Ruan profited handsomely from their pill mill operation. The government seized numerous luxury vehicles including two Ferraris and two Lamborghinis and nine other fancy cars. 301

292 See Nate Raymond, Alabama 'Pill Mill' Doctor Tied to Insys Gets 21 Years in Prison, REUTERS (May 26, 2017, 1:18 PM), https://www.reuters.com/article/us-alabama-drugs/ alabama-pill-mill-doctor-tied-to-insys-gets-21-years-in-prison-idUSKBN18M2GK [https://perma.cc/GTH6-WU98].

293 Dr. Couch and Dr. Ruan Sentenced to 240 and 252 Months in Federal Prison for Running Massive Pill Mill, U.S. Dep'T Just. U.S. Attorney's Off. S. District Ala. (May 27, 2017), https://www.justice.gov/usao-sdal/pr/dr-couch-and-dr-ruan-sentenced-240and-252-months-federal-prison-running-massive-pill [https://perma.cc/8U77-2TLU] [hereinafter Dr. Couch and Dr. Ruan Sentenced].

294 Id.

295 Id.

296 United States' Response to Defendants' Sentencing Memorandums and Positions Regarding Sentencing Factors at 8, United States v. Couch, No. 1:15-cr-00088 (S.D. Ala. May 24, 2017) [hereinafter Sentencing Response, Couch].

297 See Dr. Couch and Dr. Ruan Sentenced, supra note 293.

298 Id.

299 Sentencing Response, Couch, supra note 296, at 8, 14.

300 Id. at 8.

301 Jill Riepenhoff, Case Study: Drs. John P. Couch and Xiulu Ruan, CumberLAnd TimesNEws (Feb. 26, 2018), https://www.times-news.com/news/case-study-drs-john-p-couch- 
A jury convicted both doctors of drug distribution as well as conspiring to engage in drug distribution, health care fraud, mail and wire fraud, and kickbacks. ${ }^{302}$ Computing their drug quantity was complicated because many of their prescriptions involved opioid sprays, rather than pills, and because it was challenging to determine how much of their practice involved illegal prescriptions. ${ }^{303}$

When all of the drugs were converted to a drug weight pursuant to the Federal Sentencing Guidelines formula, the total amounted to a staggering 548 thousand kilograms of marijuana equivalent for Dr. Couch and 306 million kilograms of marijuana equivalent for Dr. Ruan. ${ }^{304}$ The government maintained that there was evidence that half of that drug weight came from illegal prescriptions, but prosecutors ultimately took the more conservative position that it was only necessary to count $10.6 \%$ of the prescriptions to ensure a very high sentence. ${ }^{305}$

Dr. Couch faced a guidelines range of 360 months to life and the government recommended 420 months. ${ }^{306}$ Dr. Ruan faced a guidelines range of life and the government recommended 480 months. ${ }^{307}$ The judge took the position that "[t]his is not a typical pill mill... Dr. Couch had gotten into a position where his practice had gotten away from him. ... And I don't think that he originally intended for it to get this way, but it got this way and it was indeed illegal."308 The judge therefore departed below the guidelines and imposed 240 months for Dr. Couch and 252 months for Dr. Ruan, ${ }^{309}$ meaning both doctors will be released from prison in their seventies.

\footnotetext{
and-xiulu-ruan/article_62ecec6a-c058-5361-af2f-cf5d65f9671b.html [https://perma.cc/ P83P-JQXR].

302 Sentencing Response, Couch, supra note 296, at 1.

303 See id. at 4-7.

304 Id. at 6.

305 See id. at 7.

306 Transcript of Sentencing of John Patrick Couch, M.D. at 79-80, United States v. Couch, No. 1:15-cr-00088 (S.D. Ala. May 26, 2017) [hereinafter Sentencing Transcript, Couch].

307 See Transcript of Sentencing of Xiulu Ruan, M.D. at 62, 64-65, United States v. Ruan, No. 1:15-cr-00088 (S.D. Ala. May 26, 2017).

308 Sentencing Transcript, Couch, supra note 306, at 87-88.

309 See Specker, supra note 2.
} 
23. Dr. Timothy Gowder: Roughly Two Million Pills, $\$ 1.7$ Million in Profit, Twenty-One Years in Prison

Federal prosecutors in Kentucky brought charges against a Tennessee doctor, Dr. Timothy Gowder, as well as two men who owned the clinic where Dr. Gowder worked. ${ }^{310}$ Prosecutors alleged that Dr. Gowder and his co-conspirators were responsible for "more than 1.6 million oxycodone 30mg pills, and hundreds of thousands of other narcotic pills and sedative pills, such as Xanax." 311 About half of the customers crossed the Kentucky border to purchase pills. ${ }^{312}$ In its forfeiture motion, the Government alleged that Dr. Gowder reaped more than $\$ 1.7$ million in profit from the pill mill. 313

A jury convicted Dr. Gowder of trafficking oxycodone and money laundering. ${ }^{314}$ The probation office calculated a guidelines range of 480 months in prison and the Government recommended the same sentence. Although Dr. Gowder was advanced in age - seventy-two years old - and his defense lawyer forcefully argued for a sentencing reduction based on age, the judge nevertheless imposed a very stiff sentence. ${ }^{315}$ While the court departed below the guidelines recommendation, the judge imposed a twenty-one-year sentence, which will keep Dr. Gowder in prison into his nineties. ${ }^{316}$

24. Dr. Sardar Ashrafkhan: Millions of Pills, Twenty-Three Years in Prison

A jury convicted Dr. Sardar Ashrafkhan of conspiracy to distribute drugs, conspiracy to commit health care fraud, and money laundering. ${ }^{317}$ Although he had been a doctor in Pakistan and

310 See Two Florida Clinic Owners, supra note 2.

311 Tom Latek, Pain Clinic Operator, Tenn. Doctor Get Lengthy Sentences, Ky. Today (Aug. 9, 2019, 4:20 PM), http://kentuckytoday.com/stories/pain-clinic-operator-tenndoctor-get-lengthy-sentences, 20948 [https://perma.cc/T6KR-WE8H].

312 See id.

313 See United States's Motion for Forfeiture Money Judgements at 5, United States v. Gowder, No. 6:17-cr-00025 (E.D. Ky. June 20, 2019).

314 See id. at 1.

315 See Motion for Downward Departure and/or Variance and Sentencing Memorandum of Defendant Timothy Gowder, M.D. at 33-34, United States v. Gowder, No. 6:17-cr-00025 (E.D. Ky. July 30, 2019).

316 See id. at 34; Latek, supra note 311.

317 Former Doctor Sentenced to 23 Years in Prison for Distributing Prescription Drugs, Health Care Fraud and Money Laundering, U.S. DeP'T JUST. U.S. AtTORNEY's OFF. E. DistRICT MiCH. (June 15, 2017), https://www.justice.gov/usao-edmi/pr/former-doctor- 
represented himself as a legitimate doctor in the United States, Dr. Ashrafkhan was never licensed to practice in the United States. ${ }^{318}$ Dr. Ashrafkhan oversaw a massive operation and hired doctors and other medical professionals to prescribe millions of pills. ${ }^{319}$

Prosecutors alleged that Dr. Ashrafkhan was responsible for over 1 million hydrocodone pills, 200,000 oxycodone pills, and 3 million dosage units of other controlled substances. ${ }^{320}$ According to prosecutors, his clinic was just a scheme in which patient marketers brought in fake patients to obtain fraudulent prescriptions for controlled substances. ${ }^{321}$ The marketers then "filled the controlled substance prescriptions at cooperating pharmacies and sold the drugs on the street market."322 Dr. Ashrafkhan also billed Medicare for millions of dollars in fraudulent medical examinations. 323

Dr. Ashrafkhan had a guidelines range of life, but that was subject to a statutory maximum of fifty years. ${ }^{324}$ Because he was the mastermind of the operation, prosecutors sought a sentence of at least 228 months so that he would receive a longer sentence than his co-conspirators. 325 The court imposed a sentence of 276 months, or twenty-three years. ${ }^{326}$

25. Dr. Gazelle Craig: 3.5 Million Pills, Las Vegas Cocktail, ThirtyFive Years in Prison

Dr. Gazelle Craig was convicted of conspiracy and multiple counts of distributing a controlled substance with no legitimate purpose. ${ }^{327} \mathrm{Dr}$.

sentenced-23-years-prison-distributing-prescription-drugs-health-care [https://perma. cc/5GDG-T6T9] [hereinafter Former Doctor Sentenced to 23 Years].

318 See E-mail from Wayne Pratt, Assistant U.S. Att'y, E.D. of Mich., to Adam M. Gershowitz, Professor of Law, William \& Mary Law Sch. (Oct. 23, 2019, 10:19 AM) (on file with author).

319 See Former Doctor Sentenced to 23 Years, supra note 317; E-mail from Wayne Pratt to Adam M. Gershowitz, supra note 318.

320 Former Doctor Sentenced to 23 Years, supra note 317.

321 See id.

322 Id.

323 See id.

324 See E-mail from Wayne Pratt, Assistant U.S. Att'y, E.D. of Mich., to Adam M. Gershowitz, Professor of Law, William \& Mary Law Sch. (Oct. 23, 2019, 8:03 AM) (on file with author).

325 See Sentencing Memorandum by the United States Regarding Sardar Ashrafkhan at 1-2, United States v. Ashrafkhan, No. 2:11-cr-20551 (E.D. Mich. May 30, 2017).

326 Transcript of Sentencing Hearing at 51, United States v. Ashrafkhan, No. 2:11-cr20551 (E.D. Mich. Aug. 9, 2017).

327 See United States' Memorandum in Aid of Sentencing and Response to Defendant's Motion for Downward Variance at 1, United States v. Craig, No. 4:17-cr- 
Craig ran a medical clinic that accepted only cash payments. ${ }^{328}$ In exchange for $\$ 300$ in cash, Dr. Craig would prescribe patients both hydrocodone and a muscle relaxant - a combination of drugs that is known by drug seekers as the "Las Vegas cocktail." 329 In the span of two-and-a-half years, Dr. Craig wrote more than 18,000 prescriptions for hydrocodone, almost all of which were for more than 100 pills. 330 She also wrote more than 15,000 prescriptions for muscle relaxants. ${ }^{331}$ That amounted to more than 2.1 million hydrocodone pills and almost 1.4 million muscle relaxant prescriptions. ${ }^{332}$ On some days, Dr. Craig's pill mill operation would bring in more than $\$ 20,000$ in cash. 333

To sell such an enormous quantity of pills, Dr. Craig relied on "facilitators" who recruited homeless people to pose as patients. ${ }^{334}$ The facilitators paid for the sham doctor visits, filled the prescriptions, and then sold the Las Vegas cocktail on the street. ${ }^{335}$ The facilitators brought in anywhere from $75 \%$ to $99 \%$ of her "patients." 336 To avoid detection, Dr. Craig banned electronic devices from her clinic. ${ }^{337}$ If "patients" were caught with a cell phone, they were either banned from the clinic or Dr. Craig reduced the quantity of pills they would receive. ${ }^{338}$

Because Dr. Craig prescribed such a huge quantity of pills, and because there was overwhelming evidence that $75 \%$ or more of the prescriptions were illegal, her guidelines range was astronomical: 860 months. ${ }^{339}$ The government argued in favor of the 860-month sentence. ${ }^{340}$ The court imposed a lower — but still extremely stiff sentence of 420 months. ${ }^{341}$ Because she was only forty-two years old, the sentence of 420 months (while very long) will result in her being released in her seventies.

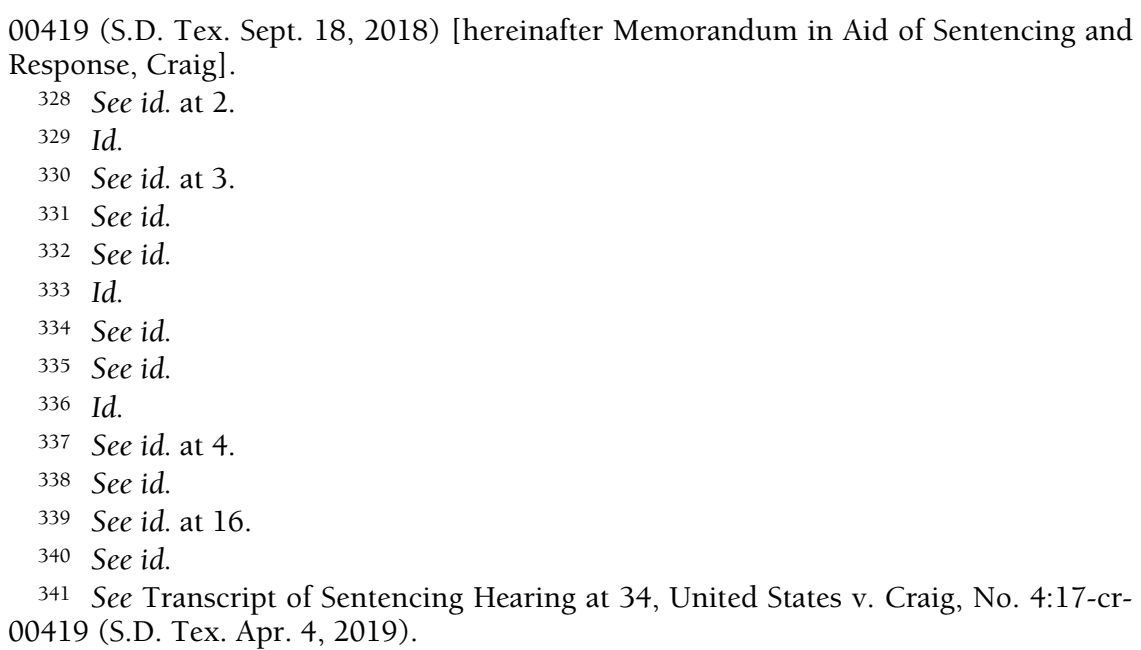


All of these pill mill cases are appalling. In each, doctors violated their Hippocratic oath to do no harm, and they clearly violated federal criminal law by prescribing drugs without a legitimate medical purpose.

Reasonable minds can differ over which cases are the worst. If our focus is primarily on the number of pills prescribed then Dr. Aggrawal, who put over twelve million pills on the streets, deserves the highest sentence. He in fact received a stiff sentence of fifteen years, but that was many years less than other pill mill doctors who had prescribed fewer doses of opioids. Moreover, if we rely on the number of pills as the primary factor in sentencing, then it is very difficult to explain the five-year sentences imposed on Drs. Richard Evans, Ernesto Lopez, and Rodney Moret. Those doctors each put well over a million pills on the street - making them among the more prolific prescribers - but they received sentences that were among the lightest of any of the pill mill doctors.

If the primary focus is on outrageous conduct that helped to facilitate the pill mills, then perhaps Dr. Zongli Chang is deserving of the most severe sentence because he conspired with patient recruiters not only to bring patients into the clinic, but also to transport them to pharmacies so that the conspirators could reclaim the drugs immediately and sell them on the street. Or one might say that Dr. Daniel Cham engaged in the most egregious facilitating behavior by selling his prescriptions in the middle of the night and backdating them to appear like they were written during normal business hours. Both Dr. Chang and Dr. Cham received tough punishments - eleven years and thirteen years respectively - though both physicians received far shorter sentences than other doctors.

Or we might simply focus on which doctors appeared to be the greediest. Doctors Couch and Ruan make a compelling case on that front. They not only ran a pill mill, but also took kickbacks from a drug manufacturer and opened their own illicit pharmacy in order to maximize their profits. They received among the longest sentences, though far less than Dr. Craig.

At the end of the day, it is difficult to find a unifying theme that explains the wide sentencing variations. Some pill mill doctors engaged in egregious conduct and received sentences of five years or less. Other doctors engaged in comparably horrifying behavior and received 15, 20, or even 35 years in prison. Put simply, from a 30,000-foot view, it is very difficult to justify the vast sentencing disparities. Part II below further complicates the search for a legitimate explanation by 
highlighting doctors who engaged in less egregious conduct but received longer sentences than many pill mill doctors.

\section{LONG SENTENCES FOR LESS EGREGIOUS MISCONDUCT}

In addition to the egregious pill mills described in Part II, there are hundreds of other doctors who have been sentenced for smaller scale drug-dealing operations. It is beyond the scope of this Article to analyze these less egregious cases in depth. Nevertheless, this Part briefly highlights a few cases in which doctors who engaged in far less egregious conduct than the pill mill doctors nevertheless received stiffer sentences. My point here is not to say that these doctors were overpunished. Nor is my goal to argue that particular pill mill doctors were under-punished. This Article does not take a position on the appropriate sentence for doctors who have illegally prescribed opioids. Instead, I set forth the less serious cases in this Part in order to show the wide inconsistency in sentencing across the country.

In 2019, Dr. Gary Hartman - a Virginia dentist — pleaded guilty to conspiracy to distribute oxycodone pills and received a sentence of 8 and $1 / 3$ years, which is longer than nine of the pill mill doctors described in Part I. ${ }^{342}$ Dr. Hartman wrote far fewer prescriptions than those pill mill doctors, and it appeared he was trying to feed his own addiction. According to the Department of Justice's press release, Dr. Hartman wrote 766 prescriptions involving about 40,000 pills of oxycodone. ${ }^{343}$ Dr. Hartman conspired with high school friends, another dentist, and impoverished members of the community in need of free dental care. ${ }^{344}$ Dr. Hartman would write the prescription to other individuals and they would bring the prescriptions back to him for his own personal use. ${ }^{345}$ There did not appear to be any allegations that Dr. Hartman intended to distribute the pills to vulnerable members of the community or that he was trying to profit off of his status as a doctor. Rather, he was feeding his own addiction.

342 See Scott Daugherty, A Virginia Beach Dentist Tried to Cover Up His Bogus Prescriptions. Thanks in Part to Alert Pharmacists, It Didn't Work, VA. Pilot (Oct. 2, 2019), https://www.pilotonline.com/news/crime/vp-nw-bogus-prescriptions-20191002dbk2mzqcuzhqtafcsbecjn6v34-story.html [https://perma.cc/C2Q5-K7QS].

343 Dentist Pleads Guilty to Running Oxycodone Conspiracy, U.S. DeP'T Just. U.S. Attorney's OfF. E. District VA. (May 9, 2019), https://www.justice.gov/usaoedva/pr/dentist-pleads-guilty-running-oxycodone-conspiracy [https://perma.cc/E92Q$\mathrm{R} 7 \mathrm{EH}]$.

344 See id.

345 Id. 
In New York, Dr. Jeffrey Gundel plead guilty to unlawfully distributing a controlled substance. ${ }^{346}$ Although he was a well-paid surgeon making $\$ 500,000$ per year, Dr. Gundel began selling oxycodone without a valid medical reason. ${ }^{347}$ Before he was caught, Dr. Gundel wrote 248 prescriptions that put 60,000 oxycodone pills on the street. ${ }^{348}$ Dr. Gundel received a sentence of seventy-eight months. ${ }^{349}$ Dr. Gundel's conduct was egregious, particularly given that he had a lucrative job and had no financial need to sell drugs. Nevertheless, the quantity of drugs he sold was very low compared to the pill mill cases described in Part I. In contrast to Dr. Gundel's 60,000 pills, Drs. Evans, Lopez, Ridgill and Sun put hundreds of thousands or even millions of pills on the street and received shorter sentences. 350

Dr. Richard Johns of Arkansas distributed an even smaller number of pills, but received a longer sentence of nine years. ${ }^{351}$ Dr. Johns plead guilty to writing 187 oxycodone prescriptions that were medically unnecessary during the period of 2011 to 2015.352 This amounted to over 16,000 oxycodone pills. ${ }^{353}$ That number, of course, is not insignificant given that each pill can be sold on the street for $\$ 30$. Yet, the total quantity is extremely small compared to the pill mill doctors who received lower sentences.

In West Virginia, which has been hit extremely hard by the opioid epidemic, a federal judge sentenced Dr. Jose Jorge Abbud Gordinho to ninety-six months in prison for distributing "more than 11,000 prescription pills" and improperly billing Medicare and Medicaid for nearly $\$ 50,000.354$ While his conduct was extremely serious and

346 Robert Gavin, Ex-Surgeon Gets 6 1/2 Years in Federal Prison for Drug Sales, TIMES UNION (Jan. 25, 2016, 8:34 PM), https://www.timesunion.com/local/article/Ex-surgeongets-6-frac12-years-in-federal-prison-6782500.php [https://perma.cc/X7AC-Q2FY].

347 Transcript of Sentencing of Jeffrey Gundel, M.D. at 5-6, United States v. Gundel, No. 1:14-cr-426 (N.D.N.Y. Jan. 25, 2016).

348 See Gavin, supra note 346.

349 See id.

350 See supra notes 52-71, 72-87, 98-110, 121-136 and accompanying text.

351 See Linda Satter, Former Little Rock Doctor Sentenced to 9 Years for Writing Fake Prescriptions, ARK. DEMOCRAT GAZETTE (Aug. 31, 2017, 4:30 AM), https://www.arkansasonline.com/news/2017/mar/03/opioid-rx-sold-internist-admits2017030/ [https://perma.cc/496B-PM8R].

352 See id.

353 Id.; see also Physician Admits to Illegally Distributing 39,000 Pills, Pleads Guilty to Federal Conspiracy, U.S. Dep't Just. U.S. AtTorney's OfF. E. District ARK. (Mar. 2, 2017) https://www.justice.gov/usao-edar/pr/physician-admits-illegally-distributing-39000pills-pleads-guilty-federal-conspiracy [https://perma.cc/4B4V-6FGS].

354 Wendy Holdren, Dr. Jose Gordinho Sentenced to Eight Years in Prison, REG. HeRALD (Apr. 27, 2016), https://www.register-herald.com/news/dr-jose-gordinho-sentenced- 
included allegations of trading sex for pills, ${ }^{355}$ an eight-year sentence for 11,000 pills was far tougher than that imposed on many pill mill doctors responsible for much larger numbers of pills. Moreover, the Probation Office calculated a guidelines range of forty-six to fifty-seven months, and the prosecutors handling the case agreed that a sentence in the guidelines range would be appropriate. ${ }^{356}$ The judge nevertheless imposed a sentence that was more than double the bottom of the guidelines range and which was far tougher than doctors who engaged in much more egregious conduct.

Even though none of these doctors were engaged in conduct as egregious as the pill mill doctors described in Part I, they all received tough sentences. One possible explanation is their age. While many pill mill operators are in their sixties or seventies, Dr. Hartman was fortynine, and Drs. Gundel and Johns were fifty-one years old. ${ }^{357}$ Because they were younger, even sentences of eight or nine years would probably not result in them dying in prison. Accordingly, the judges may not have felt the need to reduce the doctors' sentences below the guidelines range to ensure they would have life on the outside after completing their sentences. As I will explain in detail in subpart IV.B, the age of the pill mill doctors appears to play a major role in their sentences. Before considering how age (and other factors) are driving sentencing disparities though, I turn first to factors that seem relevant but which do not actually drive sentencing disparities.

\section{FACTORS THAT Do Not EXPLAIN THE SENTENCING DiSPARITIES}

Why did some of the pill mill doctors receive sentences of five years or less while other doctors received 15, 20, or 35 years? There are some

to-eight-years-in-prison/article_43354491-0a46-5d00-9102-afe7f99b5166.html [https://perma.cc/FQM6-J9GS]; see Beckley Doctor Sentenced to Eight Years in Prison for Federal Drug Crime and Health Care Fraud, U.S. DeP'T Just. U.S. AtTORNEY's OFF. S. District W. VA. (Apr. 27, 2016), https://www.justice.gov/usao-sdwv/pr/beckley-doctorsentenced-eight-years-prison-federal-drug-crime-and-health-care-fraud [https://perma. cc/6BH9-LBEP].

355 See Holdren, supra note 354.

356 See Sentencing Memorandum of the United States at 1, United States v. Gordinho, No. 5:16-cr-00007 (S.D. W. Va. Mar. 30, 2016).

357 See Daugherty, supra note 342; Satter, supra note 351; Surgeon Receives 78 Months In Prison For Distributing Oxycodone, U.S. DeP'T Just. U.S. AtTORney's OfF. N. DistRict N.Y. (Jan. 25, 2016), https://www.justice.gov/usao-ndny/pr/surgeon-receives-78months-prison-distributing-oxycodone [https://perma.cc/F5L2-N624]. Dr. Gordinho was older - sixty-seven years old — but even his sentence fits the pattern I describe in Part IV.B, infra. Even at his more advanced age, a ninety-six-month sentence would still result in him being released in his mid-seventies. 
factors that we might expect to explain the sentencing variations. For instance, when one defendant pleads guilty and receives credit for accepting responsibility, we might expect to see him receive a shorter sentence than a similar defendant who was convicted at trial. 358 Likewise, when one defendant has no criminal history, we might expect her to receive a lighter punishment than a defendant who committed a comparable crime but had multiple prior convictions. Another possible driver of sentencing disparities is the timing of sentencing. While the opioid crisis was known five years ago, the extent of the devastation has become far more apparent in the last few years. As such, we might expect judges to become more punitive in 2018 and 2019 than they were in 2015. As I explain in this Part, however, factors such as criminal history, the trial penalty, and the date of sentencing do not appear to explain the sentencing variations among pill mill doctors.

\section{A. Criminal History Is a Largely Irrelevant Explanation}

In the average criminal case, the criminal history of the defendant can be a significant factor in increasing a defendant's sentence. Imagine a defendant with a base offense level of thirty under the Federal Sentencing Guidelines. If that defendant has no prior convictions, his criminal history category is I and his guidelines range is 97 to 121 months. If that defendant had prior convictions though (and thus a higher criminal history category) his range would increase dramatically as follows: Category II (108 to 135 months), Category III (121 to 151 months), Category IV (135 to 168 months), Category V (151 to 188 months), and Category VI (168 to 210 months). ${ }^{359}$ Our hypothetical defendant's sentence could nearly double based on his criminal history.

While criminal history can be a major factor in street drug cases, it explains very little in pill mill cases because the doctors almost never have prior convictions. This is likely because doctors have never engaged in or been caught engaging in serious criminal activity. Moreover, if the doctors committed prior criminal acts, there is a good chance that they would have lost their medical licenses and DEA licenses 360 and thus would not be in a position to prescribe drugs. As

358 See 18 U.S.C. app. § 3E1.1 (U.S. SENTENCING COMM'N 2018) (providing a twolevel decrease for acceptance of responsibility and the possibility of an additional onelevel decrease upon motion of the government for timely notifying authorities of his intention to plead guilty).

359 See id. ch. 5, pt. A.

360 See Milton Heumann, Brian Pinaire \& Jennifer Lerman, Prescribing Justice: The Law and Politics of Discipline for Physician Felony Offenders, 17 B.U. PUB. INT. L.J. 1, 2425 (2007) (studying New Jersey Medical Board disciplinary actions following certain 
such, it should not be surprising that only one of the twenty-five doctors in Part I appeared to have significant prior convictions that raised his criminal history category under the Federal Sentencing Guidelines. ${ }^{361}$ In short, criminal history played almost no role in the sentencing variations among pill mill doctors.

\section{B. Sentences Did Not Become Longer in Later Years as the Opioid Crisis Became Well Known}

Public awareness of the opioid crisis has increased dramatically over the last few years. While the basic facts about the crisis were certainly known by 2015, the magnitude of the problem was not yet apparent. It was not until late 2017 that the Department of Health and Human Services declared the opioid crisis to be a public health emergency. ${ }^{362} \mathrm{~A}$ wave of highly regarded books about the crisis were published in 2018.363 And news coverage about the opioid crisis in general has exploded over the last few years. ${ }^{364}$ As news coverage and public awareness have increased, one might expect it to affect judges' sentencing decisions. In particular, one might expect the huge amount of news coverage to cause judges to be deeply offended by the doctors who contributed to the opioid crisis. In turn, we might expect judges to impose tougher sentences on pill mill doctors in the years after the crisis

felony convictions and finding that 57\% surrendered their licenses or had them revoked).

361 Dr. Ridgill had previously been convicted of mail fraud and Medicare fraud on separate occasions, which raised his criminal history category to level II. See Reporter's Transcript, Ridgill, supra note 104, at 35, 37. Nevertheless, he ended up with one of the lightest sentences of the pill mill doctors - five years. See supra note 110 and accompanying text.

362 HHS Acting Secretary Declares Public Health Emergency to Address National Opioid Crisis, U.S. Dep'T Health \& Hum. Services (Oct. 26, 2017), https://www.hhs. gov/about/news/2017/10/26/hhs-acting-secretary-declares-public-health-emergencyaddress-national-opioid-crisis.html [https://perma.cc/V3MX-YMT9].

363 For a few notable examples, see BeTH MACy, DOPESICK: DEALERS, DOCTORS, AND the Drug Company That Addicted America (2018); Chris McGreal, American Overdose: The Opioid Tragedy in Three Acts (2018); Barry Meier, Pain Killer: An EMPIRE OF DECEIT AND THE ORIGIN OF AMERICA's OpIOID EPIDEMIC (2018). For an earlier (and important) book, see Sam Quinones, Dreamland: The True Tale of America's OPIATE EPIDEMIC (2015).

364 See Emma E. McGinty, Elizabeth M. Stone, Alene Kennedy-Hendricks, Kaylynn Sanders, Alexa Beacham \& Colleen L. Barry, U.S. News Media Coverage of Solutions to the Opioid Crisis, 2013-2017, 126 Preventive MEd., 2019, at 105771, 3 ("Volume of news media coverage of solutions to the opioid epidemic increased over the study period, from 272 news stories mentioning solutions to the opioid epidemic in 2013 to 2816 news stories in 2017."). 
became well known. In particular, we might expect that judges would not depart below the guidelines when sentencing pill mill doctors. Yet, the twenty-five cases do not show such a trend. As Table 1 demonstrates, even in 2018 and 2019 — in the middle of wall-to-wall news coverage about the opioid crisis — judges continued to impose sentences below the advisory guidelines.

Table 1. Sentencing by Year

\begin{tabular}{|c|c|c|c|c|}
\hline Doctor & $\begin{array}{l}\text { Guidelines } \\
\text { Range }\end{array}$ & Sentence & $\begin{array}{l}\text { Year of } \\
\text { Sentencing }\end{array}$ & $\begin{array}{l}\text { Below or } \\
\text { Within } \\
\text { Guidelines } \\
\text { Sentence }\end{array}$ \\
\hline $\begin{array}{l}\text { Christopher } \\
\text { Stegawski }\end{array}$ & $\begin{array}{l}293-365 \\
\text { months (but } \\
\text { subject to } \\
240 \text { month } \\
\text { statutory } \\
\text { maximum) }\end{array}$ & $\begin{array}{l}160 \\
\text { months }\end{array}$ & 2015 & Below \\
\hline Andrew Sun & $\begin{array}{l}63-78 \\
\text { months }\end{array}$ & $\begin{array}{l}63 \\
\text { months }\end{array}$ & 2015 & Within \\
\hline $\begin{array}{l}\text { Pravin } \\
\text { Mehta }\end{array}$ & $\begin{array}{l}51-78 \\
\text { months }\end{array}$ & $\begin{array}{l}24 \\
\text { months }\end{array}$ & 2016 & Below \\
\hline $\begin{array}{l}\text { Michael } \\
\text { Minas }\end{array}$ & $\begin{array}{l}\text { 151-188 } \\
\text { months }\end{array}$ & $\begin{array}{l}96 \\
\text { months }\end{array}$ & 2016 & Below \\
\hline $\begin{array}{l}\text { Moshe } \\
\text { Mirilashvili }\end{array}$ & $\begin{array}{l}151-188 \\
\text { months }\end{array}$ & $\begin{array}{l}160 \\
\text { months }\end{array}$ & 2016 & Within \\
\hline Rafael Beier & $\begin{array}{l}188-235 \\
\text { months }\end{array}$ & $\begin{array}{l}192 \\
\text { months }\end{array}$ & 2017 & Within \\
\hline $\begin{array}{l}\text { Shelinder } \\
\text { Aggarwal }\end{array}$ & $\begin{array}{l}\text { Binding Plea } \\
\text { Deal for } 180 \\
\text { months }\end{array}$ & $\begin{array}{l}180 \\
\text { months }\end{array}$ & 2017 & Within \\
\hline $\begin{array}{l}\text { Sardar } \\
\text { Ashrafkhan }\end{array}$ & Life & $\begin{array}{l}276 \\
\text { months }\end{array}$ & 2017 & Below \\
\hline $\begin{array}{l}\text { Noel } \\
\text { Blackman }\end{array}$ & $\begin{array}{l}57-71 \\
\text { months }\end{array}$ & $\begin{array}{l}50 \\
\text { months }\end{array}$ & 2017 & Below \\
\hline John Couch & $\begin{array}{l}360 \text { months } \\
\text { to Life }\end{array}$ & $\begin{array}{l}240 \\
\text { months }\end{array}$ & 2017 & Below \\
\hline $\begin{array}{l}\text { Richard } \\
\text { Arthur } \\
\text { Evans } \\
\end{array}$ & $\begin{array}{l}70-87 \\
\text { months }\end{array}$ & $\begin{array}{l}60 \\
\text { months }\end{array}$ & 2017 & Below \\
\hline Xiulu Ruan & Life & $\begin{array}{l}252 \\
\text { months }\end{array}$ & 2017 & Below \\
\hline
\end{tabular}




\begin{tabular}{|c|c|c|c|c|}
\hline Paul Ruble & $\begin{array}{l}\text { Statutory } \\
\text { Maximum } \\
\text { of } 60 \\
\text { months }\end{array}$ & $\begin{array}{l}60 \\
\text { months }\end{array}$ & 2017 & Within \\
\hline $\begin{array}{l}\text { Daniel } \\
\text { Cham }\end{array}$ & $\begin{array}{l}151-188 \\
\text { months }\end{array}$ & $\begin{array}{l}160 \\
\text { months }\end{array}$ & 2018 & Within \\
\hline $\begin{array}{l}\text { Gazelle } \\
\text { Craig }\end{array}$ & 860 months & $\begin{array}{l}420 \\
\text { months }\end{array}$ & 2018 & Below \\
\hline $\begin{array}{l}\text { Donovan } \\
\text { Dixon }\end{array}$ & $\begin{array}{l}235-293 \\
\text { months }\end{array}$ & $\begin{array}{l}240 \\
\text { months }\end{array}$ & 2018 & Within \\
\hline $\begin{array}{l}\text { Alan } \\
\text { Godofsky }\end{array}$ & $\begin{array}{l}121-151 \\
\text { months }\end{array}$ & $\begin{array}{l}60 \\
\text { months }\end{array}$ & 2018 & Below \\
\hline $\begin{array}{l}\text { Edward } \\
\text { Ridgill }\end{array}$ & $\begin{array}{l}87-108 \\
\text { months }\end{array}$ & $\begin{array}{l}60 \\
\text { months }\end{array}$ & 2018 & Below \\
\hline $\begin{array}{l}\text { Rodney } \\
\text { Moret }\end{array}$ & $\begin{array}{l}97-121 \\
\text { months }\end{array}$ & $\begin{array}{l}75 \\
\text { months }\end{array}$ & 2018 & Below \\
\hline $\begin{array}{l}\text { Dwight } \\
\text { Bailey }\end{array}$ & $\begin{array}{l}\text { 151-188 } \\
\text { months }\end{array}$ & $\begin{array}{l}151 \\
\text { months }\end{array}$ & 2019 & Within \\
\hline $\begin{array}{l}\text { Zongli } \\
\text { Chang } \\
\end{array}$ & $\begin{array}{l}108-135 \\
\text { months }\end{array}$ & $\begin{array}{l}135 \\
\text { months }\end{array}$ & 2019 & Within \\
\hline $\begin{array}{l}\text { Timothy } \\
\text { Gowder }\end{array}$ & 480 months & $\begin{array}{l}252 \\
\text { months }\end{array}$ & 2019 & Below \\
\hline $\begin{array}{l}\text { Ernesto } \\
\text { Lopez }\end{array}$ & $\begin{array}{l}360 \text { months } \\
\text { to Life }\end{array}$ & $\begin{array}{l}60 \\
\text { months }\end{array}$ & 2019 & Below \\
\hline Tad Taylor & 240 months & $\begin{array}{l}240 \\
\text { months }\end{array}$ & 2019 & Within \\
\hline $\begin{array}{l}\text { Carlos } \\
\text { Venegas }\end{array}$ & $\begin{array}{l}240 \text { months } \\
\text { pursuant to } \\
\text { statutory } \\
\text { maximum }\end{array}$ & $\begin{array}{l}156 \\
\text { months }\end{array}$ & 2019 & Below \\
\hline
\end{tabular}

Roughly half (twelve) of the doctors analyzed in this Article were sentenced in 2018 or 2019 after a huge amount of news coverage about the opioid crisis. In seven of those twelve cases the judges sentenced the doctors below the guidelines range. Indeed, some of the largest variances occurred in 2019. Dr. Lopez faced a guidelines range of 360 months to life, but he received a sixty-month sentence. ${ }^{365}$ Dr. Venegas was punished with a 156-month sentence rather than the 240-month recommended guidelines sentence. ${ }^{366}$ Moreover, of the five cases where

365 See supra notes 79, 87 and accompanying text.

366 See supra notes 192, 196 and accompanying text. 
judges sentenced the defendants within the guidelines range in 2018 and 2019, the judges imposed sentences toward the bottom end of the guidelines. In short, at least in the twenty-five pill mill cases analyzed in this Article, it does not appear that sentencing the doctors after massive news coverage about the opioid crisis deterred judges from imposing lower sentences than we might expect.

\section{Losing at Trial (Rather Than Pleading Guilty) Does Not Seem to Explain Sentencing Variations}

One common explanation for sentencing variations in the criminal justice system is the trial penalty. ${ }^{367}$ The conventional wisdom is that defendants who turn down plea deals and go to trial end up with longer sentences than if they had plea bargained. It is difficult to test the "trial penalty" theory in the pill mill context because we do not know what plea deals the doctors were offered and turned down. We can assess a related phenomenon though: When a doctor goes to trial and loses, do judges sentence the doctors toward the top of the guidelines range, rather than imposing sentences on the lower end of the range?368 Relatedly, when a doctor pleads guilty, does he tend to receive a sentence at the bottom end of the guidelines range or even below the guidelines?

In at least one pill mill case, the prosecution specifically argued against a sentence on the lower end of the guideline range because the defendant exercised his right to go to trial. Dr. Couch was convicted at trial of illegally prescribing drugs and receiving kickbacks from the manufacturer. He faced a guidelines range of 360 months to life. ${ }^{369} \mathrm{At}$ sentencing, the prosecutor argued:

Based on the findings so far from the Court that it's an offense level of 42 with a criminal history category I, that puts the ... low end of the guideline ... at 360 months . . 360 months, the low end is what we would have recommended, or any low end is what we recommend in a plea agreement, not after a seven-

367 See, e.g., Norman L. Reimer \& Martin Antonio Sabelli, The Tyranny of the Trial Penalty: The Consensus That Coercive Plea Practices Must End, 31 FED. SEnT'G ReP. 215, 215 (2019) (defining trial penalty as the variation in sentencing for defendants who accept a pre-trial offer and defendants who defend themselves in court).

368 There are anecdotal stories of judges imposing a top-of-the-guidelines penalty on defendants for going to trial. See, e.g., People v. Pennington, 323 Mich. App. 452, 469 (2018) (explaining that "the judge's sentencing policy was to impose the maximum recommended guidelines sentence when a defendant was convicted after going to trial" and finding the practice to be unlawful).

369 See Sentencing Transcript, Couch, supra note 306, at 79. 
and-a-half week trial where we put on all the evidence and prove up each of the counts against the defendants. ${ }^{370}$

The prosecutors' approach would certainly be consistent with the theory that defendants are penalized at sentencing for going to trial. Yet, that theory did not hold for Dr. Couch. The court imposed a belowGuidelines sentence of 240 months. ${ }^{371}$ And the trial penalty did not hold for most other pill mill doctors either. As Table 2 below demonstrates, eighteen of the twenty-five pill mill doctors studied in Part I went to trial. In twelve of the eighteen cases, the court imposed sentences below the guidelines, even after hearing all of the appalling evidence during lengthy trials. Put differently, two-thirds of the doctors convicted at trial did not even receive sentences in the guidelines range - they were sentenced below the guidelines range. Indeed, in some of the cases, the court imposed sentences well below the guidelines. For instance, after a jury trial, Dr. Lopez receive a sentence six times lower than the bottom of the range. 372

Table 2. Lack of Sentencing Penalties for Doctors Who Went to Trial

\begin{tabular}{|c|c|c|c|c|c|}
\hline Doctor & $\begin{array}{l}\text { Trial } \\
\text { or } \\
\text { Plea }\end{array}$ & $\begin{array}{l}\text { Guidelines } \\
\text { Range }\end{array}$ & Sentence & $\begin{array}{l}\text { Difference } \\
\text { Between } \\
\text { Sentence } \\
\text { and } \\
\text { Bottom of } \\
\text { the } \\
\text { Guidelines } \\
\text { Range }\end{array}$ & $\begin{array}{l}\text { Does It } \\
\text { Appear } \\
\text { Possible } \\
\text { That } \\
\text { Defendant } \\
\text { Was } \\
\text { Penalized } \\
\text { for Going } \\
\text { to Trial? }\end{array}$ \\
\hline $\begin{array}{l}\text { Richard } \\
\text { Arthur } \\
\text { Evans }\end{array}$ & Trial & $\begin{array}{l}70-87 \\
\text { months }\end{array}$ & $\begin{array}{l}60 \\
\text { months }\end{array}$ & $-14.29 \%$ & No \\
\hline $\begin{array}{l}\text { Ernesto } \\
\text { Lopez }\end{array}$ & Trial & $\begin{array}{l}360 \\
\text { months to } \\
\text { Life }\end{array}$ & $\begin{array}{l}60 \\
\text { months }\end{array}$ & $-83.33 \%$ & No \\
\hline $\begin{array}{l}\text { Alan } \\
\text { Godofsky }\end{array}$ & Trial & $\begin{array}{l}\text { 121-151 } \\
\text { months }\end{array}$ & $\begin{array}{l}60 \\
\text { months }\end{array}$ & $-50.42 \%$ & No \\
\hline $\begin{array}{l}\text { Edward } \\
\text { Ridgill }\end{array}$ & Trial & $\begin{array}{l}87-108 \\
\text { months }\end{array}$ & $\begin{array}{l}60 \\
\text { months }\end{array}$ & $-31.04 \%$ & No \\
\hline
\end{tabular}

370 Id.

371 See supra note 309 and accompanying text.

372 See supra notes 79, 87 and accompanying text. 
[Vol. 54:1053

\begin{tabular}{|c|c|c|c|c|c|}
\hline $\begin{array}{l}\text { Andrew } \\
\text { Sun }\end{array}$ & Trial & $\begin{array}{l}63-78 \\
\text { months }\end{array}$ & $\begin{array}{l}63 \\
\text { months }\end{array}$ & $0 \%$ & No \\
\hline $\begin{array}{l}\text { Michael } \\
\text { Minas }\end{array}$ & Trial & $\begin{array}{l}\text { 151-188 } \\
\text { months }\end{array}$ & $\begin{array}{l}96 \\
\text { months }\end{array}$ & $-36.43 \%$ & No \\
\hline $\begin{array}{l}\text { Dwight } \\
\text { Bailey }\end{array}$ & Trial & $\begin{array}{l}\text { 151-188 } \\
\text { months }\end{array}$ & $\begin{array}{l}151 \\
\text { months }\end{array}$ & $0 \%$ & No \\
\hline $\begin{array}{l}\text { Carlos } \\
\text { Venegas }\end{array}$ & Trial & $\begin{array}{l}240 \\
\text { months } \\
\text { pursuant } \\
\text { to } \\
\text { statutory } \\
\text { maximum }\end{array}$ & $\begin{array}{l}156 \\
\text { months }\end{array}$ & $-35.0 \%$ & No \\
\hline $\begin{array}{l}\text { Moshe } \\
\text { Mirilashvili }\end{array}$ & Trial & $\begin{array}{l}\text { 151-188 } \\
\text { months }\end{array}$ & $\begin{array}{l}160 \\
\text { months }\end{array}$ & $+5.96 \%$ & $\begin{array}{l}\text { Possible, } \\
\text { but } \\
\text { unlikely }\end{array}$ \\
\hline $\begin{array}{l}\text { Christopher } \\
\text { Stegawski }\end{array}$ & Trial & $\begin{array}{l}293-365 \\
\text { months } \\
\text { (but } \\
\text { subject to } \\
240- \\
\text { month } \\
\text { statutory } \\
\text { maximum) }\end{array}$ & $\begin{array}{l}160 \\
\text { months }\end{array}$ & $-33.33 \%$ & No \\
\hline Rafael Beier & Trial & $\begin{array}{l}\text { 188-235 } \\
\text { months }\end{array}$ & $\begin{array}{l}192 \\
\text { months }\end{array}$ & $+2.13 \%$ & $\begin{array}{l}\text { Possible, } \\
\text { but } \\
\text { unlikely }\end{array}$ \\
\hline $\begin{array}{l}\text { Donovan } \\
\text { Dixon }\end{array}$ & Trial & $\begin{array}{l}235-293 \\
\text { months }\end{array}$ & $\begin{array}{l}240 \\
\text { months }\end{array}$ & $+2.13 \%$ & $\begin{array}{l}\text { Possible, } \\
\text { but } \\
\text { unlikely }\end{array}$ \\
\hline Tad Taylor & Trial & $\begin{array}{l}240 \\
\text { months }\end{array}$ & $\begin{array}{l}240 \\
\text { months }\end{array}$ & $0 \%$ & Possibly \\
\hline John Couch & Trial & $\begin{array}{l}360 \\
\text { months to } \\
\text { Life }\end{array}$ & $\begin{array}{l}240 \\
\text { months }\end{array}$ & $-33.33 \%$ & No \\
\hline Xiulu Ruan & Trial & Life & $\begin{array}{l}252 \\
\text { months }\end{array}$ & - & No \\
\hline $\begin{array}{l}\text { Timothy } \\
\text { Gowder }\end{array}$ & Trial & $\begin{array}{l}480 \\
\text { months }\end{array}$ & $\begin{array}{l}252 \\
\text { months }\end{array}$ & $-47.50 \%$ & No \\
\hline $\begin{array}{l}\text { Sardar } \\
\text { Ashrafkhan }\end{array}$ & Trial & Life & $\begin{array}{l}276 \\
\text { months }\end{array}$ & -- & No \\
\hline $\begin{array}{l}\text { Gazelle } \\
\text { Craig }\end{array}$ & Trial & $\begin{array}{l}860 \\
\text { months }\end{array}$ & $\begin{array}{l}420 \\
\text { months }\end{array}$ & $-51.16 \%$ & No \\
\hline
\end{tabular}


Of the six remaining cases, two doctors received sentences at the bottom of the guidelines range. Only four of the eighteen pill doctors who went to trial received a sentence above the bottom of the guidelines range. And in three of those cases, the sentences were only barely above the bottom of the range. ${ }^{373}$ In only one case - Dr. Taylor - did the doctor receive a sentence at the top of the range after going to trial, and even then, other factors may have led to the tough sentence. At sentencing, Dr. Taylor demonstrated a lack of remorse and made brazen and baseless accusations that the prosecutors had committed misconduct. ${ }^{374}$

Of course, it is not possible to draw definitive conclusions from a sample of only eighteen cases, especially when we do not know what plea bargain offers the prosecution may have offered prior to trial. But the available evidence does not indicate that sentencing variations occurred because certain doctors were penalized by going to trial.

\section{Location of the Prosecution Does Not Explain Sentencing Variations}

Another theory for sentencing disparities is the location of the pill mill cases. Some areas of the United States have been hit much harder by the opioid crisis. One might imagine that judges in those locations would be tougher on pill mill doctors because they were one of the root causes of the opioid crisis. Once again, it is difficult to draw definitive conclusions because some of the most massive pill mills were not located in the heart of the opioid crisis. ${ }^{375}$ Nevertheless, the pill mill cases in this Article do not support the theory that judges meted out tougher sentences in areas hit harder by the opioid crisis. Consider the following examples.

Dr. Pravin Mehta was running a pill mill in Niagara Falls, New York. 376 Niagara County had the highest rate of opioid pills of any county in the state of New York. ${ }^{377}$ Yet, a judge imposed a sentence of

373 Drs. Mirilashvili, Beier, and Dixon all received sentences that were much closer to the bottom than the top of the guidelines range.

374 See supra note 288 and accompanying text.

375 Some of the pill mills analyzed in this Article were located in large cities such as New York City, Los Angeles, and Houston, that were not what most experts think of as the areas hardest hit by the opioid crisis. Finding huge pill mills in big cities makes sense given that there must be a large enough "patient" base to consume the huge number of pills.

376 Pfeiffer, supra note 5.

377 Michael Wooten, Opioid Rate Higher in Niagara County than Anywhere in the State, WGRZ (July 22, 2019, 7:35 PM EDT), http://www.wgrz.com/article/news/opioid-rate- 
twenty-four months for Dr. Mehta, which was less than half of the advisory guidelines range. 378

The City of Dayton was said to be ground zero for Ohio's opioid crisis. ${ }^{379}$ Dr. Christopher Stegawski was convicted of selling opioids for cash and breaking back into a pill mill clinic that had been shuttered by law enforcement. Dr. Stegawski's guidelines range was 293 to 365 months, subject to a 240-month statutory maximum. Yet, despite Dayton's well-known opioid problem, the judge imposed a sentence of 160 months - well below the guidelines range.

The Commonwealth of Kentucky has arguably been hit harder by the opioid crisis than almost any other state. In 2018, the rate of opioid deaths in Kentucky was nearly double the national average. ${ }^{380}$ Yet, when Dr. Alan Godofsky was sentenced in 2018, the court did not follow the guidelines range of 121 to 151 months. Instead, the judge imposed a sentence of sixty months. ${ }^{381}$

Alabama had the highest per capita opioid prescribing rate in 2016.382 There were 121 prescriptions for every 100 persons in Alabama. ${ }^{383}$ In Mobile, Alabama, Drs. John Couch and Xiulu Ruan received stiff sentences for running one of the nation's most notorious pill mills. Still, both doctors received sentences that were well below the guidelines. Dr. Couch received 240 months, which was far below the guidelines range of 360 months to life. ${ }^{384}$ And Dr. Ruan received 252 months, rather than the guidelines range of life imprisonment. ${ }^{385}$ While Drs. Couch and

higher-in-niagara-county-than-anywhere-in-the-state/71-ff5e3061-66b6-4730-bf51-

8eb006387cd6 [https://perma.cc/J9DZ-U47V].

378 See supra notes 39-41 and accompanying text.

379 See Katie Wedell, Dayton Cut Overdose Deaths in Half — and Learned These Lessons to Prevent Another Crisis, DAYTON DAIly News (Mar. 10, 2019), http://www.daytondailynews.com/news/local/dayton-cut-overdose-deaths-half-nowmodel-for-addressing-addiction/siwxOxBukiAYmKPA51NbTO/ [https://perma.cc/9DKCTLBF].

380 See Kentucky: Opioid-Involved Deaths and Related Harms, NAT'L INST. ON DRUG ABUSE, http://www.drugabuse.gov/drug-topics/opioids/opioid-summaries-by-state/ kentucky-opioid-involved-deaths-related-harms (last visited Sept. 20, 2020) [https://perma.cc/X2L7-7YT6].

381 See supra notes 95-96 and accompanying text.

382 Understanding the Opioid Crisis, Ala. Dep't Mental Health, http://mh.alabama.gov/understanding-the-opioid-crisis/ (last visited Sept. 20, 2020) [https://perma.cc/E6VX-B8SS].

383 Id.

384 See supra notes 306, 309 and accompanying text.

385 See supra notes 307, 309 and accompanying text. 
Ruan will be locked up for a long time, they will both likely leave prison in their early seventies, rather than dying behind bars. ${ }^{386}$

At least $40 \%$ of the opioids that flooded the state of Michigan landed in the Detroit metro area. ${ }^{387}$ Overdose deaths skyrocketed in that area. The three main counties making up the Detroit metro area saw opioid overdose deaths rise from sixty-two in 1999 to more than 1,000 in 2017. ${ }^{388}$ Yet, two doctors from that area - Dr. Rodney Moret and Dr. Sardar Ashrafkhan - received below guidelines sentences in two separate pill mill cases. ${ }^{389}$

Of course, these examples do not mean that judges never impose within-guidelines sentences in areas that were hit hard by the opioid crisis. But these examples do undermine the theory that sentencing variations are being driven by whether the jurisdiction was hit hard by the opioid crisis.

\section{FACTORS THAT DO CONTRIBUTE TO SENTENCING DisPaRitieS}

There are two factors that do appear to explain sentencing variations in prosecutions against pill mill doctors. These two factors - age and the difficulty of computing drug quantity - have received little attention in the literature about the opioid crisis and white-collar prosecutions more generally. I begin with the difficulty of computing drug quantity when the defendants are white-collar physicians.

\section{A. The Difficulty of Computing Drug Quantity in Pill Mill Cases Explains Some of the Sentencing Disparities}

The Federal Sentencing Guidelines put enormous emphasis on the weight of the drugs in computing a sentence. For instance, if a

386 See supra note 309 and accompanying text; see also Public Records: Health Care Providers, LEXISNExIS, https://advance.lexis.com/publicrecordshome/?pdmfid=1000200 \&pdbcts $=1603774268689 \&$ prid $=545 \mathrm{~b} 366 \mathrm{e}-\mathrm{e} 5 \mathrm{a} 5-4 \mathrm{~b} 84-\mathrm{ab} 09-8 \mathrm{be} 80 \mathrm{bb} 5 \mathrm{fff}$ c $\& \mathrm{crid}=$ 8ble5161-8376-4e7b-85be-3d405d5edfa5 (last visited October 26, 2020) [https://perma.cc/FD57-ZYNZ] (stating Dr. Couch's year of birth as 1965); Public Records: Health Care Providers, LEXISNEXIS, https://advance.lexis.com/publicrecordshome/ ?pdmfid $=1000200 \&$ pdbcts $=1603774268689 \&$ prid $=545$ b366e-e5a5-4b84-ab09-

8be80bb5fffc\&crid=8ble5161-8376-4e7b-85be-3d405d5edfa5 (last visited October 26, 2020) [https://perma.cc/4DU7-L2S2] (stating Dr. Ruan's year of birth as 1963).

387 See Susan Vela, Data: Metro Detroit Pharmacies Received More than 40 Percent of State's Pain Pill Supplies, HOMETOWN LIFE (Sept. 24, 2019, 1:21 PM ET), http://www.hometownlife.com/story/news/local/hometown/2019/09/24/metro-detroitreceived-millions-pain-pills-2006-2012/2346756001/ [https://perma.cc/7QPB-7WFT].

388 See id.

389 See supra notes 149-151, 324-326 and accompanying text. 
defendant is convicted of a single count of possession with intent to distribute cocaine, he faces a statutory sentencing range of up to twenty years under 21 U.S.C. \& 841. Under the Federal Sentencing Guidelines, if the amount of cocaine is small - for instance, 150 grams - the base offense level is sixteen months and the advisory sentencing range is twenty-one to twenty-seven months for a defendant with no criminal history. If the defendant is held responsible for one kilogram of cocaine, however, the base offense level jumps to twenty-four and the guidelines range increases to fifty-one to sixty-three months. And if the cocaine weight is twenty kilograms the base offense level rises to level thirtyfour and the sentencing guidelines suggest a range of 151 to 188 months. 390

Under the guidelines, the defendant can be held responsible not only for the drug weight charged in the indictment and for which he is convicted at trial, but also for relevant conduct. Under Guideline $\S 1 \mathrm{Bl} .3(\mathrm{a})(2)$, if the government proves by a preponderance of the evidence that the defendant was distributing additional drugs as part of the same course of conduct or common scheme, he can be charged with the added weight. ${ }^{391}$ In street drug cases, it is not usually difficult for the government to prove relevant conduct because street drugs cocaine, heroin, and other illicit substances - are always illegal.

Pill mill cases are quite different, however. Doctors have DEA licenses authorizing them to prescribe opioids. If a doctor is seeing some legitimate patients it becomes difficult to know what number of pills the doctor should be held responsible for. Put differently, the judge cannot increase the sentence based on legitimate prescriptions that a doctor wrote to patients who actually needed painkillers. The prosecution can only add uncharged, relevant conduct if the pills were for illegitimate purposes. And the prosecutors have to work hard to prove that the prescriptions were illegitimate. They must hire expert witnesses - other doctors - to review patient files and opine that there was no legitimate reason for the defendant to prescribe drugs to those patients. ${ }^{392}$ Utilizing medical experts is time-consuming and expensive.

390 The base offense levels for these examples are drawn from the drug quantity table in Federal Sentencing Guideline \& 2D1.1(C). See U.S. Sentencing Comm'n, U.S. SENTENCING GUIDELINES MANUAL \& 2D1.1(C) (2018). The sentencing ranges are found in the Sentencing Table in Part V of the Guidelines. See id. at ch. 5, pt. A.

391 See id. § 1B1.3(a)(2); U.S. Sentencing Comm'N, Primer: Relevant Conduct 2 (2020).

392 See Adam M. Gershowitz, The Opioid Doctors: Is Losing Your License a Sufficient Penalty for Dealing Drugs? 36-37 (unpublished manuscript) (on file with author) (arguing for additional funding for prosecutors to hire medical experts). 
To avoid the time and cost of hiring medical experts and having them review large numbers of files, prosecutors sometimes decline to push for the maximum drug weight. One way they do this is by only asking the court to consider a shortened period that the pill mill was operating. For instance, in the case of Dr. Ridgill, the government only sought to include the drug weight for a single year, even though the pill mill operated for longer. ${ }^{393}$ According to prosecutors, "[i]f the Government actually covered the entirety of defendant's prescription history ... the offense level [and thus the guidelines range] would be ... through the roof." 394

The other way that prosecutors ignore some of the drug weight is by conceding that a percentage of the doctor's practice was legitimate. For instance, prosecutors might believe that $90 \%$ of the prescriptions a doctor wrote were illegitimate, but proving that by a preponderance of the evidence can be difficult. So prosecutors may argue for a lower percentage. Rather than contending that 500,000 out of 1 million pills should be counted toward the drug weight, they may instead only ask for 100,000 out of the 1 million pills to be counted. Prosecutors took this approach, for example, with Drs. Couch and Ruan. Although they had testimony to support counting half of the practice's drug weight in computing the guidelines, they took the conservative position that only $10 \%$ of the prescriptions should be counted because that percentage alone would result in a very long sentence. 395

Unsurprisingly, when cases plea bargain, there is significant opportunity for the government and the defense to take large numbers of pills off the table. A defendant who was running a massive pill mill involving millions of doses of opioids might enter into a plea deal with prosecutors that counts only a tiny fraction of the prescriptions in computing the sentence. For example, although there was evidence that Dr. Chang prescribed more than 2.7 million opioid doses, his plea agreement counted less $10 \%$ of that amount — only about 330,000 pills. 396

Similarly, consider the case of Dr. Moret, who ran a pain clinic from 2010 to 2015. Dr. Moret was likely responsible "for illegally distributing over 700,000 dosage units of Hydrocodone, (Vicodin, loratab), more than 240,000 dosage units of Alprazolam, and more than 2 million milliliters of promethazine with codeine cough syrup, worth more than

393 See supra note 104 and accompanying text.

394 Reporter's Transcript, Ridgill, supra note 104, at 24.

395 See Sentencing Response, Couch, supra note 296, at 7-9.

396 See supra notes 167, 170 and accompanying text. 
\$15 million on the street market." 397 Prosecutors reached a plea deal with Dr. Moret that carried a sentencing range of 97 to 121 months. ${ }^{398}$ To reach that sentencing range, the plea agreement counted the illegal hydrocodone prescriptions but it "did not use any oxycodone unnecessarily prescribed by defendant in calculating his sentencing guidelines." 399 Leaving out the oxycodone shaved two base offense level points off of Dr. Moret's guidelines range, ${ }^{400}$ which reduced his range from 121 to 151 months down to 97 to 121 months. ${ }^{401}$

The court likely under-counted the drug quantity in Dr. Godofsky's case as well. He saw seventy patients per day and handed out prescriptions for more than 500,000 oxycodone pills. Yet, not all of the pills were counted at sentencing. As the prosecutor explained:

The number of pills that Dr. Godofsky is being held responsible for really could be substantially higher had the United States essentially gone through the entire patient list and sought out each of those patients during the time frame to be considered relevant conduct. He has already received a more than substantial break considering that the amount of pills attributable to him is far less than the 500,000 pills that he distributed during that course of time that he was at that clinic. 402

Even the court agreed that Dr. Godofsky "received a break in terms of the drug quantity." 403

Thus, the total number of pills distributed by the doctors does not tell us the full story. Rather, what matters is the number of pills the parties either agree upon in the plea deal or the number of pills the prosecutor can prove at a contested sentencing hearing. Accordingly, when news reports or even allegations by prosecutors tell us that a doctor

397 Former Doctor Sentenced to 75 Months, supra note 137.

398 Government's Sentencing Memorandum, Moret, supra note 148, at 4.

399 Id. at 12.

400 See id. at 11-13.

401 See U.S. Sentencing Comm'n, U.S. Sentencing Guidelines Manual ch. 5, pt. A (2018). At sentencing, prosecutors advocated for a sentence at the top of the guidelines range - 121 months. Perhaps they thought that they could forego the oxycodone prescriptions in the guidelines calculation (thus giving up the 121 to 151-month range) because the judge would follow their recommendation and sentence Dr. Moret at the top of the lower guideline range of 97 to 121 months. If that was their strategy though, it did not work. The judge departed downward and sentenced Dr. Moret to seventy-five months. See Former Doctor Sentenced to 75 Months, supra note 137.

402 Transcript of Sentencing, Godofsky, supra note 5, at 29.

403 Id. at 32. 
distributed over a million pills, that allegation (even if it is backed by common sense and some evidence) will not necessarily result in a huge sentence because not all of the drug weight will be counted by the court at sentencing.

The decision not to pursue the total drug quantity in pill mill cases may also help to explain how doctors engaged in less egregious conduct sometimes receive sentences that are similar to pill mill doctors. For example, Dr. Nicholas Capos, a cardiologist, maintained a legitimate medical practice but prescribed opioids on the side. ${ }^{404}$ Those prescriptions were illegal. Dr. Capos did not perform physical examinations and he ignored signs that patients were abusing or selling the pills. ${ }^{405} \mathrm{He}$ faced a sentencing range of seventy to eighty-seven months. ${ }^{406}$ This sentencing range was comparable to the range for many pill mill doctors, even though Dr. Capos was distributing a much smaller number of pills. ${ }^{407}$ The reason is likely because it was easy for prosecutors and the court to prove that the prescriptions were illegal. Unlike pain doctors, dentists, and internists, a cardiologist will not typically have a legitimate reason to prescribe oxycodone to his patients.

At bottom, the difficulty of computing drug quantity helps to explain the vastly different guidelines ranges of some pill mill doctors. Because many pill mill doctors are general practitioners or pain management specialists, it is possible that some of their opioid prescriptions were legitimate. Because it is time-consuming and expensive for prosecutors to show the total number of illegitimate pills, they take understandable shortcuts that reduce the quantity at sentencing. In turn, in some cases,

404 See Associated Press, Doctor Sentenced for Prescribing Thousands of Opioid Pills, SEATtle Times (Feb. 22, 2018, 4:49 PM), http://www.seattletimes.com/nationworld/doctor-sentenced-for-prescribing-thousands-of-opioid-pills/ [https://perma.cc/ M8XT-3NEN].

405 Physician Practicing in Grass Valley and Yuba City Sentenced to over 4 Years in Prison for Illegal Prescription Practice, U.S. DEP'T JuST. U.S. ATtORNEY's OfF. E. DistRICT CAL. (Feb. 22, 2018), https://www.justice.gov/usao-edca/pr/physician-practicing-grassvalley-and-yuba-city-sentenced-over-4-years-prison-illegal [https://perma.cc/9V4VA2C3] [hereinafter Physician Practicing in Grass Valley].

406 Plea Agreement at 8, United States v. Capos, No. 2:14-cr-00020 (E.D. Cal. May 5, 2016). Ultimately, the court imposed a below-guidelines sentence of fifty-two months. See Physician Practicing in Grass Valley, supra note 405.

407 See Kathy Robertson, Granite Bay Doctor Indicted on Suspicion of Distributing Oxycodone, SACRAMENTO BUS. J. (Jan. 31, 2014, 2:07 PM EST), http://www. bizjournals.com/sacramento/news/2014/01/31/doc-capos-distribute-oxcodone-charged. html [https://perma.cc/8DK7-N7NS] (discussing the comparatively lower amount of 1,590 oxycodone pills Dr. Capos allegedly distributed). 
the actual drug quantity distributed by the doctors (and what is reported in news stories) may not be the driving force in sentencing. ${ }^{408}$

The difficulty of proving drug quantity does not tell the whole story on sentencing variations though. If it did, we would see fairly modest guidelines ranges and judges typically sentencing within those ranges. Many cases do not fit that pattern, however. As Table 3 demonstrates below, about half of the pill mill cases carried huge guidelines ranges of 188 months (over fifteen years) or above. In these cases, prosecutors were likely able to demonstrate a large drug quantity. Yet, the court imposed sentences that were much lower. Put differently, many of the pill mill cases involved high guidelines ranges, but judges ended up imposing sentences below the guidelines. Table 3 shows that judges sentenced fifteen of the twenty-five pill mill doctors in this study below the guidelines range. And in many of the cases, the judges imposed sentences far below the guidelines range.

Table 3. Judges Imposed Below Guidelines Sentences in Fifteen of the Twenty-Five Pill Mill Cases

\begin{tabular}{|c|c|c|c|}
\hline Doctor & $\begin{array}{l}\text { Guidelines } \\
\text { Range }\end{array}$ & Sentence & $\begin{array}{l}\text { Below or Within } \\
\text { Guidelines }\end{array}$ \\
\hline Pravin Mehta & 51-78 months & 24 months & Below \\
\hline $\begin{array}{l}\text { Noel } \\
\text { Blackman }\end{array}$ & 57-71 months & 50 months & Below \\
\hline $\begin{array}{l}\text { Richard } \\
\text { Arthur Evans }\end{array}$ & 70-87 months & 60 months & Below \\
\hline Ernesto Lopez & $\begin{array}{l}360 \text { months } \\
\text { to Life }\end{array}$ & 60 months & Below \\
\hline Alan Godofsky & $\begin{array}{l}\text { 121-151 } \\
\text { months }\end{array}$ & 60 months & Below \\
\hline Edward Ridgill & $\begin{array}{l}87-108 \\
\text { months }\end{array}$ & 60 months & Below \\
\hline Paul Ruble & $\begin{array}{l}\text { Statutory } \\
\text { Maximum of } \\
60 \text { months }\end{array}$ & 60 months & Within \\
\hline Andrew Sun & $63-78$ months & 63 months & Within \\
\hline Rodney Moret & $\begin{array}{l}97-121 \\
\text { months }\end{array}$ & 75 months & Below \\
\hline Michael Minas & $\begin{array}{l}\text { 151-188 } \\
\text { months }\end{array}$ & 96 months & Below \\
\hline
\end{tabular}

408 The cases of Drs. Mehta, Blackman, Ridgill, Moret, and Sun appear to fit this pattern. 


\begin{tabular}{|c|c|c|c|}
\hline Zongli Chang & $\begin{array}{l}108-135 \\
\text { months }\end{array}$ & 135 months & Within \\
\hline Dwight Bailey & $\begin{array}{l}\text { 151-188 } \\
\text { months }\end{array}$ & 151 months & Within \\
\hline $\begin{array}{l}\text { Carlos } \\
\text { Venegas }\end{array}$ & $\begin{array}{l}240 \text { months } \\
\text { (pursuant to } \\
\text { statutory } \\
\text { maximum) }\end{array}$ & 156 months & Below \\
\hline Daniel Cham & $\begin{array}{l}151-188 \\
\text { months }\end{array}$ & 160 months & Within \\
\hline $\begin{array}{l}\text { Moshe } \\
\text { Mirilashvili }\end{array}$ & $\begin{array}{l}\text { 151-188 } \\
\text { months }\end{array}$ & 160 months & Within \\
\hline $\begin{array}{l}\text { Christopher } \\
\text { Stegawski }\end{array}$ & $\begin{array}{l}293-365 \\
\text { months (but } \\
\text { subject to } 240 \\
\text { month } \\
\text { statutory } \\
\text { maximum) }\end{array}$ & 160 months & Below \\
\hline $\begin{array}{l}\text { Shelinder } \\
\text { Aggarwal }\end{array}$ & $\begin{array}{l}\text { Binding Plea } \\
\text { Deal for } 180 \\
\text { months }\end{array}$ & 180 months & Within \\
\hline Rafael Beier & $\begin{array}{l}188-235 \\
\text { months }\end{array}$ & 192 months & Within \\
\hline John Couch & $\begin{array}{l}360 \text { months } \\
\text { to Life }\end{array}$ & 240 months & Below \\
\hline $\begin{array}{l}\text { Donovan } \\
\text { Dixon }\end{array}$ & $\begin{array}{l}235-293 \\
\text { months }\end{array}$ & 240 months & Within \\
\hline Tad Taylor & 240 months & 240 months & Within \\
\hline Xiulu Ruan & Life & 252 months & Below \\
\hline $\begin{array}{l}\text { Timothy } \\
\text { Gowder }\end{array}$ & 480 months & 252 months & Below \\
\hline $\begin{array}{l}\text { Sardar } \\
\text { Ashrafkhan }\end{array}$ & Life & 276 months & Below \\
\hline Gazelle Craig & 860 months & 420 months & Below \\
\hline
\end{tabular}

The large number of below-guidelines cases indicates that there is more to the sentencing disparity story than simply computing the drug quantity. Put differently, when a defendant faces a guidelines range of 360 months to life, but instead receives a much shorter sentence of sixty months in prison, there must be an explanation other than drug quantity driving the sentencing disparity. As detailed in subpart III.B 
below, the age of the doctors appears to be a major driving force in sentencing disparities.

\section{B. Age Appears to Play a Major Role in Sentencing Outcomes}

[T] he Court does not and is not of the opinion that a sentence that would place a 72-year-old man in prison for life essentially would be an appropriate sentence.

$$
\text { - United States v. Evans (S.D. Tex. 2017) } 409
$$

[I] f you commit a crime on the scale of your narcotics operation when you're in your mid-60s then you have to do your punishment while you are old. You are no less deserving of punishment because you were old when you . . . engaged in this nefarious behavior.

$$
\text { - United States v. Mirilashvili (S.D.N.Y. 2016) } 410
$$

Initially, the Federal Sentencing Guidelines instructed judges that a defendant's age was "not ordinarily relevant" in determining whether to impose a sentence outside the guidelines range. ${ }^{411}$ In 2010, the Commission amended the guidelines to provide that age can be a relevant consideration when its effects are present to an unusual degree and distinguish the case from other cases. ${ }^{412}$ The policy statement now provides as follows:

Age (including youth) may be relevant in determining whether a departure is warranted, if considerations based on age, individually or in combination with other offender characteristics, are present to an unusual degree and distinguish the case from the typical cases covered by the guidelines. Age may be a reason to depart downward in a case in which the defendant is elderly and infirm and where a form of punishment such as home confinement might be equally efficient as and less costly than incarceration. Physical condition, which may be related to age, is addressed at 5H1.4. ${ }^{413}$

Age plays a major role in sentencing disparities among pill mill doctors. Before analyzing those disparities though, it is important to first

409 Transcript of Sentencing, Evans, supra note 21, at 61.

410 Transcript of Sentencing, Mirilashvili, supra note 225, at 37.

411 See Jenness, supra note 17, at 30.

412 See id.

413 U.S. Sentencing Comm'N, U.S. Sentencing Guidelines Manual § 5H1.1 (2018) (emphasis added). 
understand that doctors charged with illegally prescribing opioids are much older than the typical criminal defendants. In a related article, I have gathered data about more than 150 doctors sentenced for illegally prescribing opioids between 2015 and 2019.414 This dataset includes not just pill mill doctors but also less serious misconduct. Of the roughly 150 doctors for whom I have found age information, more than seventy of them were sixty years-of-age or older when sentenced. Another fortyfive of those doctors were in their fifties when sentenced. Only a small fraction of doctors were under the age of fifty. This phenomenon is also true of pill mill doctors who engaged in the most egregious misconduct. Of the twenty-five doctors studied in this Article, sixteen were sixty years old or older. Only three of the twenty-five doctors were under or at the age of fifty at sentencing. ${ }^{415}$

The next question then is whether the doctors' older age affects sentencing outcomes. The answer is "yes," but the story takes two steps of analysis to understand. Of the sixteen pill mill doctors who were age sixty or older, the judges imposed sentences below the guidelines in nine cases. This data, by itself, is not particularly telling because in the remaining nine cases (involving doctors under the age of sixty) the judges imposed sentences below the guidelines in five of the cases. Thus, as Table 4 demonstrates, it does not appear, at least initially, that older doctors are more likely to receive a sentencing break.

Table 4. Both Older and Younger Doctors Received Sentences Below the Guidelines

\begin{tabular}{|l|l|l|}
\hline $\begin{array}{l}\text { Doctors (Arranged by } \\
\text { Age) }\end{array}$ & $\begin{array}{l}\text { Age at } \\
\text { Sentencing }\end{array}$ & $\begin{array}{l}\text { Below or Within } \\
\text { Guidelines }\end{array}$ \\
\hline Andrew Sun & 79 & Within \\
\hline Pravin Mehta & 77 & Below \\
\hline Ernesto Lopez & 75 & Below \\
\hline Timothy Gowder & 72 & Below \\
\hline Richard Arthur Evans & 72 & Below \\
\hline Moshe Mirilashvili & 68 & Within \\
\hline Noel Blackman & 68 & Below \\
\hline Rodney Moret & 67 & Below \\
\hline Dwight Bailey & 66 & Within \\
\hline Tad Taylor & 65 & Within \\
\hline Christopher Stegawski & 65 & Below \\
\hline Edward Ridgill & 65 & Below \\
\hline
\end{tabular}

414 See Gershowitz, supra note 16, at 5-6.

415 See infra Table 4. 


\begin{tabular}{|l|l|l|}
\hline Paul Ruble & 64 & Within \\
\hline Rafael Beier & 63 & Within \\
\hline Carlos Venegas & 62 & Within \\
\hline Alan Godofsky & 61 & Below \\
\hline Sardar Ashrafkhan & 59 & Below \\
\hline Xiulu Ruan & 54 & Below \\
\hline Zongli Chang & 53 & Within \\
\hline John Couch & 51 & Below \\
\hline Donovan Dixon & 51 & Within \\
\hline Michael Minas & 50 & Below \\
\hline Daniel Cham & 49 & Within \\
\hline Shelinder Aggarwal & 48 & Within \\
\hline Gazelle Craig & 42 & Below \\
\hline
\end{tabular}

The more interesting observation is not the age of the doctors in a vacuum but the projected age of the doctors when they will be released from prison. Here we can start to see that some judges are tailoring their sentences to ensure that the doctors will have some life left after serving their prison terms. Judges seem to be choosing sentences that ensure that doctors will be released in their seventies. And if the doctors are already over seventy years old, the judges seem to be imposing shorter sentences that will allow the doctors to be released before they turn eighty. Table 5 highlights the age at release and shows that some doctors are receiving steep sentencing reductions to ensure release in their seventies.

Table 5. Age at Release: Sentencing Reductions to Ensure Doctors Are Released in Their Seventies

\begin{tabular}{|l|l|l|l|l|}
\hline Doctor & $\begin{array}{l}\text { Guidelines } \\
\text { Range }\end{array}$ & Sentence & $\begin{array}{l}\text { Age at } \\
\text { Sentencing }\end{array}$ & $\begin{array}{l}\text { Approximate } \\
\text { Age at } \\
\text { Release }\end{array}$ \\
\hline $\begin{array}{l}\text { Pravin } \\
\text { Mehta }\end{array}$ & $\begin{array}{l}51-78 \\
\text { months }\end{array}$ & $\begin{array}{l}24 \\
\text { months }\end{array}$ & 77 & 79 \\
\hline $\begin{array}{l}\text { Noel } \\
\text { Blackman }\end{array}$ & $\begin{array}{l}57-71 \\
\text { months }\end{array}$ & $\begin{array}{l}50 \\
\text { months }\end{array}$ & 68 & 72 \\
\hline
\end{tabular}

416 This calculation does not take account of good-time credit because it is speculative, nor does it consider time served prior to pronouncement of sentences because there was insufficient information to make that determination. Accordingly, it is possible that the age of release could be a few years younger. 


\begin{tabular}{|c|c|c|c|c|}
\hline $\begin{array}{l}\text { Richard } \\
\text { Arthur } \\
\text { Evans }\end{array}$ & $\begin{array}{l}70-87 \\
\text { months }\end{array}$ & $\begin{array}{l}60 \\
\text { months }\end{array}$ & 72 & 77 \\
\hline $\begin{array}{l}\text { Ernesto } \\
\text { Lopez }\end{array}$ & $\begin{array}{l}360 \\
\text { months to } \\
\text { Life }\end{array}$ & $\begin{array}{l}60 \\
\text { months }\end{array}$ & 75 & 80 \\
\hline $\begin{array}{l}\text { Alan } \\
\text { Godofsky }\end{array}$ & $\begin{array}{l}121-151 \\
\text { months }\end{array}$ & $\begin{array}{l}60 \\
\text { months }\end{array}$ & 61 & 66 \\
\hline $\begin{array}{l}\text { Edward } \\
\text { Ridgill }\end{array}$ & $\begin{array}{l}87-108 \\
\text { months }\end{array}$ & $\begin{array}{l}60 \\
\text { months }\end{array}$ & 65 & 70 \\
\hline Paul Ruble & $\begin{array}{l}\text { Statutory } \\
\text { Maximum } \\
\text { of } 60 \\
\text { months }\end{array}$ & $\begin{array}{l}60 \\
\text { months }\end{array}$ & 64 & 69 \\
\hline Andrew Sun & $\begin{array}{l}63-78 \\
\text { months }\end{array}$ & $\begin{array}{l}63 \\
\text { months }\end{array}$ & 79 & 84 \\
\hline $\begin{array}{l}\text { Rodney } \\
\text { Moret }\end{array}$ & $\begin{array}{l}97-121 \\
\text { months }\end{array}$ & $\begin{array}{l}75 \\
\text { months }\end{array}$ & 67 & 74 \\
\hline $\begin{array}{l}\text { Michael } \\
\text { Minas }\end{array}$ & $\begin{array}{l}151-188 \\
\text { months }\end{array}$ & $\begin{array}{l}96 \\
\text { months }\end{array}$ & 50 & 58 \\
\hline $\begin{array}{l}\text { Zongli } \\
\text { Chang }\end{array}$ & $\begin{array}{l}108-135 \\
\text { months }\end{array}$ & $\begin{array}{l}135 \\
\text { months }\end{array}$ & 53 & 65 \\
\hline $\begin{array}{l}\text { Dwight } \\
\text { Bailey }\end{array}$ & $\begin{array}{l}\text { 151-188 } \\
\text { months }\end{array}$ & $\begin{array}{l}151 \\
\text { months }\end{array}$ & 66 & 79 \\
\hline $\begin{array}{l}\text { Carlos } \\
\text { Venegas }\end{array}$ & $\begin{array}{l}240 \\
\text { months } \\
\text { (pursuant } \\
\text { to statutory } \\
\text { maximum) }\end{array}$ & $\begin{array}{l}56 \\
\text { months }\end{array}$ & 62 & 75 \\
\hline $\begin{array}{l}\text { Daniel } \\
\text { Cham }\end{array}$ & $\begin{array}{l}151-188 \\
\text { months }\end{array}$ & $\begin{array}{l}160 \\
\text { months }\end{array}$ & 49 & 63 \\
\hline $\begin{array}{l}\text { Moshe } \\
\text { Mirilashvili }\end{array}$ & $\begin{array}{l}\text { 151-188 } \\
\text { months }\end{array}$ & $\begin{array}{l}160 \\
\text { months }\end{array}$ & 68 & 82 \\
\hline $\begin{array}{l}\text { Christopher } \\
\text { Stegawski }\end{array}$ & $\begin{array}{l}293-365 \\
\text { months } \\
\text { (but } \\
\text { subject to } \\
240 \text { month } \\
\text { statutory } \\
\text { maximum) }\end{array}$ & $\begin{array}{l}160 \\
\text { months }\end{array}$ & 65 & 79 \\
\hline
\end{tabular}




\begin{tabular}{|l|l|l|l|l|}
\hline $\begin{array}{l}\text { Shelinder } \\
\text { Aggarwal }\end{array}$ & $\begin{array}{l}\text { Binding } \\
\text { Plea Deal } \\
\text { for 180 } \\
\text { months }\end{array}$ & $\begin{array}{l}\text { l80 } \\
\text { months }\end{array}$ & 48 & 63 \\
\hline Rafael Beier & $\begin{array}{l}188-235 \\
\text { months }\end{array}$ & $\begin{array}{l}192 \\
\text { months }\end{array}$ & 63 & 79 \\
\hline John Couch & $\begin{array}{l}360 \\
\text { months to } \\
\text { Life }\end{array}$ & $\begin{array}{l}240 \\
\text { months }\end{array}$ & 51 & 71 \\
\hline $\begin{array}{l}\text { Donovan } \\
\text { Dixon }\end{array}$ & $\begin{array}{l}235-293 \\
\text { months }\end{array}$ & $\begin{array}{l}240 \\
\text { months }\end{array}$ & 51 & 71 \\
\hline Tad Taylor & $\begin{array}{l}240 \\
\text { months }\end{array}$ & $\begin{array}{l}240 \\
\text { months }\end{array}$ & 65 & 85 \\
\hline Xiulu Ruan & $\begin{array}{l}\text { Life } \\
\text { months }\end{array}$ & $\begin{array}{l}252 \\
\text { months }\end{array}$ & 72 & 75 \\
\hline $\begin{array}{l}\text { Timothy } \\
\text { Gowder }\end{array}$ & $\begin{array}{l}480 \\
\text { months }\end{array}$ & $\begin{array}{l}276 \\
\text { months }\end{array}$ & 59 & 82 \\
\hline $\begin{array}{l}\text { Sardar } \\
\text { Ashrafkhan }\end{array}$ & Life & $\begin{array}{l}420 \\
\text { months }\end{array}$ & 42 & 77 \\
\hline $\begin{array}{l}\text { Gazelle } \\
\text { Craig }\end{array}$ & $\begin{array}{l}860 \\
\text { months }\end{array}$ & & 93 \\
\hline
\end{tabular}

Some doctors fit this pattern particularly well. In the cases of Drs. Evans, Lopez, Venegas, Couch, Ruan, Stegawski, Ashrafkhan, and Craig, the judges imposed sentences well below the guidelines that ensured the doctors would be released in their seventies or, at worst, their early eighties. Had the courts imposed the bottom end of the guidelines range for these eight doctors they almost certainly would have died in prison. Table 6 shows the drastic sentencing reductions that judges made to ensure that these doctors would - like other pill mill doctors - have a chance at life on the outside of prison. 
Table 6. Steep Sentencing Reductions to Avoid Life or Long Sentences for Older Defendants

\begin{tabular}{|c|c|c|c|c|c|}
\hline Doctor & $\begin{array}{l}\text { Guidelines } \\
\text { Range }\end{array}$ & $\begin{array}{l}\text { Age at } \\
\text { Sentencing }\end{array}$ & Sentence & $\begin{array}{l}\text { Age at } \\
\text { Release } \\
\text { Under } \\
\text { Actual } \\
\text { Sentence }\end{array}$ & $\begin{array}{l}\text { Age at } \\
\text { Release If } \\
\text { Judge Had } \\
\text { Sentenced } \\
\text { at the } \\
\text { Bottom of } \\
\text { the } \\
\text { Guidelines } \\
\text { Range }\end{array}$ \\
\hline $\begin{array}{l}\text { Richard } \\
\text { Arthur } \\
\text { Evans }\end{array}$ & $\begin{array}{l}70-87 \\
\text { months }\end{array}$ & 72 & $\begin{array}{l}60 \\
\text { months }\end{array}$ & 77 & 78 \\
\hline $\begin{array}{l}\text { Ernesto } \\
\text { Lopez }\end{array}$ & $\begin{array}{l}360 \text { months } \\
\text { to Life }\end{array}$ & 75 & $\begin{array}{l}60 \\
\text { months }\end{array}$ & 80 & 105 \\
\hline $\begin{array}{l}\text { Carlos } \\
\text { Venegas }\end{array}$ & $\begin{array}{l}240 \text { months } \\
\text { pursuant to } \\
\text { statutory } \\
\text { maximum }\end{array}$ & 62 & $\begin{array}{l}156 \\
\text { months }\end{array}$ & 75 & 82 \\
\hline $\begin{array}{l}\text { Christopher } \\
\text { Stegawski }\end{array}$ & \begin{tabular}{|l|}
$293-365$ \\
months \\
(but subject \\
to 240 \\
month \\
statutory \\
maximum)
\end{tabular} & 65 & $\begin{array}{l}160 \\
\text { months }\end{array}$ & 79 & 85 \\
\hline John Couch & $\begin{array}{l}360 \text { months } \\
\text { to Life }\end{array}$ & 51 & $\begin{array}{l}240 \\
\text { months }\end{array}$ & 71 & 81 \\
\hline Xiulu Ruan & Life & 54 & $\begin{array}{l}252 \\
\text { months }\end{array}$ & 75 & No Release \\
\hline $\begin{array}{l}\text { Sardar } \\
\text { Ashrafkhan }\end{array}$ & Life & 59 & \begin{tabular}{|l|}
276 \\
months
\end{tabular} & 82 & No Release \\
\hline \begin{tabular}{l|l} 
Gazelle \\
Craig
\end{tabular} & 860 months & 42 & $\begin{array}{l}420 \\
\text { months }\end{array}$ & 77 & 113 \\
\hline
\end{tabular}

The most plausible explanation for the huge sentencing disparities in these pill mill cases is that judges appear to have a release age in mind and that they are subtracting the defendant's current age and then imposing a sentence that makes the math work.

In this regard, it is likely not a coincidence that four doctors - Mehta, Bailey, Stegawski, and Beier — received sentences that would result in 
release at age seventy-nine. Judges likely did not want to imprison octogenarians and may have simply computed their sentences by taking the age of seventy-nine and subtracting the defendant's current age.

Table 7. Multiple Pill Mill Doctors Received a Sentence Resulting in Release at Age Seventy-Nine

\begin{tabular}{|l|l|l|l|l|}
\hline Doctor & $\begin{array}{l}\text { Guidelines } \\
\text { Range }\end{array}$ & $\begin{array}{l}\text { Age at } \\
\text { Sentencing }\end{array}$ & Sentence & $\begin{array}{l}\text { Release Age } \\
\text { Under } \\
\text { Actual } \\
\text { Sentence }\end{array}$ \\
\hline $\begin{array}{l}\text { Pravin } \\
\text { Mehta }\end{array}$ & $\begin{array}{l}56-71 \\
\text { months }\end{array}$ & 77 & $\begin{array}{l}24 \\
\text { months }\end{array}$ & 79 \\
\hline $\begin{array}{l}\text { Christopher } \\
\text { Stegawski }\end{array}$ & $\begin{array}{l}293-365 \\
\text { months } \\
\text { (but subject } \\
\text { to 240 } \\
\text { month } \\
\text { statutory } \\
\text { maximum) }\end{array}$ & 65 & $\begin{array}{l}160 \\
\text { months }\end{array}$ & 79 \\
\hline $\begin{array}{l}\text { Dwight } \\
\text { Bailey }\end{array}$ & $\begin{array}{l}\text { 15l-188 } \\
\text { months }\end{array}$ & 66 & $\begin{array}{l}151 \\
\text { months }\end{array}$ & 79 \\
\hline Ralph Beier & $\begin{array}{l}188-235 \\
\text { months }\end{array}$ & 63 & $\begin{array}{l}192 \\
\text { months }\end{array}$ & 79 \\
\hline
\end{tabular}

In multiple cases, judges openly acknowledged the importance of the doctors' age in their decisions to impose lighter sentences. For instance, in Dr. Venegas's case, the guidelines range exceeded the statutory maximum of twenty years. In response to the government's persuasive argument for a twenty-year statutory maximum sentence, the judge remarked:

With respect to the Government's position, I'm not discounting the seriousness of the offense conduct here at all, but I don't believe it merits a life sentence, which is practically what the Guidelines are. I think the Doctor deserves to have at least some realistic chance of serving his sentence and having a life on the outside, and this is not a perfect number, but this is what the best I can do, trying to approximate respecting the seriousness of the offense conduct and the Guidelines and balancing that with the Defendant's age.

So I'm going to sentence the defendant to 156 months . . which is 13 years, and that would put the Doctor at, allowing [good time] credit, probably 74-ish when he gets out. And I think 
that's certainly a serious sentence as the conduct here deserves, but I do think I should give the Doctor some hope of being free on the outside at the conclusion of the sentence. ${ }^{417}$

In Texas, Dr. Evans faced a guidelines range of seventy to eighty-seven months for running an egregious pill mill in which he distributed 1.6 million pills. The judge sentenced him to sixty months, however. In explaining the sentence, the judge said "the Court does not and is not of the opinion that a sentence that would place a 72-year-old man in prison for life essentially would be an appropriate sentence." 418 Instead, the court imposed a five-year sentence that ensured Dr. Evans would be released by age seventy-seven at the latest.

Similarly, a federal judge in New York gave Dr. Lopez a dramatic sentencing reduction. The guidelines suggested a sentence of 360 months to life, but the judge imposed sixty months. In explaining the sentence, the court noted that "[h]e is 75 years old ... He's had two strokes. He is diabetic. So I have to take these conditions into account in deciding what an appropriate sentence is." 419

On the opposite side of the country, a federal judge in California also explicitly recognized the defendant's age when sentencing Dr. Ridgill, who was sixty-five. Despite a guidelines range of 87 to 108 months, the court imposed a sentence of sixty months, which would result in release around age seventy. In announcing the sentence, the court noted that "[i]n sentencing the defendant, the Court has considered his age." 420

In Ohio, a federal judge acknowledged considering Dr. Stegawski's age in departing from the probation office's recommended sentence of 240 months down to 160 months. ${ }^{421}$ As a result, Dr. Stegawski will leave no later than age seventy-nine, rather than age eighty-five if the court had imposed a sentence at the bottom of the guidelines range.

The pattern also holds for younger physicians. Dr. Craig faced a guidelines range of 860 months - more than seventy years — for

417 Transcript of Sentencing, Venegas, supra note 191, at 47-48. Dr. Venegas was sixty-two years old and sentenced to thirteen years, which would result in release at age seventy-five. Defendants are eligible for fifty-four days of good-time credit per year though. See 18 U.S.C. § 3624(b)(1) (2018). Good-time credit thus has the potential, but not guarantee, to shave a few years off Dr. Venegas's sentence. See id. ("II]f the Bureau determines that, during that year, the prisoner has not satisfactorily complied with such institutional regulations, the prisoner shall receive no such credit toward service of the prisoner's sentence or shall receive such lesser credit as the Bureau determines to be appropriate.").

418 Transcript of Sentencing, Evans, supra note 21, at 61.

419 Transcript of Sentencing, Lopez, supra note 79, at 53.

420 Reporter's Transcript, Ridgill, supra note 104, at 36.

421 See Transcript of Proceedings, Stegawski, supra note 6, at 31, 43-44. 
distributing over 3.5 million pills of hydrocodone and muscle relaxers. 422 Even at her young age of forty-two, that would have resulted in a prison stay past the age of 100. Perhaps sensing the judges are reluctant to impose life sentences on pill mill doctors, the prosecutors sought the guidelines sentence, but noted that a reduced sentence of 420 months would be acceptable in their eyes if the court wanted to "afford Craig an opportunity to be released from prison." 423 The court imposed that 420 month-sentence (35 years), which gives Dr. Craig an opportunity to be released in her seventies at the latest.

While age appears to play a major factor in numerous below guidelines sentences, not all judges were influenced by the doctors' advanced age. Most notably, the judge who sentenced Dr. Mirilishvilli seemed to be particularly resistant to age playing a role in his sentence, explaining that:

Your very fine lawyer says most eloquently that I should not sentence you to a lifetime of imprisonment. He says that you are an old man .... To which I say if you commit a crime on the scale of your narcotics operation when you're in your mid-60s then you have to do your punishment while you are old. You are no less deserving of punishment because you were old when you [] engaged in this nefarious behavior. ${ }^{424}$

Similarly, when Dr. Taylor's lawyer argued for a lower sentenced based on him being sixty-five years of age, the court rejected the argument and explained "[a]nd as far as the age, well, I mean, you're younger than I am, Dr. Taylor. You're younger than the people running for president, younger than the speaker of the house. I think you've got a lot of good years left in you. I hope I do." 425

The cases of Dr. Mirilishvilli and Dr. Taylor appear to be outliers though. Considerable evidence supports the conclusion that the age of the doctors plays a major role in their eventual sentence. Judges appear to (1) give shorter sentences to older doctors; and (2) tailor sentence length to ensure that most defendants will be released from prison in their seventies. To be clear, this is a descriptive claim, not a criticism. There are legitimate reasons why judges may want to take account of defendants' advanced age in their sentencing decisions, including costs and compassion. I am not making a normative claim that all pill mill

422 See supra notes 332, 339 and accompanying text.

423 Memorandum in Aid of Sentencing and Response, Craig, supra note 327, at 14.

424 Transcript of Sentencing, Mirilashvili, supra note 225, at 37.

425 Transcript of Sentencing, Taylor, supra note 285, at 44. 
doctors should spend the rest of their lives in prison. Rather, I am highlighting the evidence that the defendants' age plays a substantial factor and thus results in massive sentencing variations.

\section{CONCLUSION}

Scholars have long recognized that sentences for drug offenders can be too harsh and that there are sentencing disparities based on race and class. ${ }^{426}$ By contrast, there has been very little attention paid to sentencing disparities among white-collar offenders and little focus on how the offenders' age impacts their sentencing outcomes.

This Article analyzed a discrete population - pill mill doctors engaged in wide-scale distribution of opioids - and demonstrated massive sentencing variations. Even though the pill mill cases involved with similar conduct, similar criminal charges, and similarly overwhelming evidence, federal judges imposed vastly different punishments. Some doctors received as little as two to four years, while other doctors were sentenced to 15, 20, or even 35 years in prison.

The most likely explanations for sentencing variations - the number of prescriptions, the quantity of pills, the decision to go to trial rather than plead guilty, and whether the doctors were sentenced after the opioid crisis became obvious - do not appear to explain the vastly different sentences. Rather, the age of the doctors seems to have a major impact on the sentence they will receive. Older doctors in their seventies typically received very short sentences that seemed tailored to guarantee their release before death. Middle-aged doctors in their late fifties and early sixties often received longer sentences, but those punishments also seemed tailored to ensure they would be released while in their seventies. And younger doctors in their forties and early fifties received much long sentences that also seemed to ensure release before they would die in prison.

The twenty-five pill mill cases analyzed in this Article also demonstrate that the difficulty of determining the drug quantity in white-collar cases has a major impact on sentencing. Because doctors can lawfully prescribe opioids, they can argue that a substantial percentage of their prescriptions were legitimate and thus should not count as relevant conduct at sentencing. Prosecutors must therefore

426 See, e.g., Dorothy E. Roberts, The Social and Moral Cost of Mass Incarceration in African American Communities, 56 STAN. L. REV. 1271, 1275 (2004) (providing examples of racial disparities in drug offenses); William J. Stuntz, Race, Class, and Drugs, 98 COLUM. L. REV. 1795, 1799 (1998) (discussing how the drug trade is segmented by class). 
spend time and resources (including hiring medical experts) to mine patient data in order to prove which prescriptions should be included as relevant conduct at sentencing. That task is difficult, and when prosecutors exercise their discretion not to pursue some prescriptions, the result is sentencing disparities among doctors who engaged in similar misconduct.

There is no easy fix for the sentencing variations. With respect to the difficulty in proving the relevant drug quantity, there is no procedural rule that is unfairly hindering prosecutors. Nor would it be wise to lower the burden of proof prosecutors must meet to show relevant drug conduct. If anything, in street drug cases it is arguably too easy for prosecutors to ratchet up sentences by linking huge quantities of drugs to conspirators involved in street dealing. ${ }^{427}$ Instead, the best solution in white-collar drug cases involving doctors is simply to provide prosecutors with the necessary resources to handle time-consuming and complicated cases. The Department of Justice needs to adequately staff opioid prosecutions and it must provide increased funding to hire medical experts who can analyze and testify about doctors' prescribing practices.

The solution to sentencing disparities based on age is likewise difficult. The current guideline ( $\S 5 \mathrm{H} 1.1$ ) clearly indicates that age should be a factor rarely and only in "unusual" or atypical cases. Yet, in pill mill cases - and likely in other white-collar prosecutions - federal judges are relying frequently and substantially on the age of the offender in making sentencing decisions. The Sentencing Commission could of course rescind Guideline $\S 5 \mathrm{Hl} .1$, or it could even forbid judges from considering age as a factor. 428 Given that policymakers are seeking to reduce mass incarceration and that the recently enacted First Step Act specifically allows for age-based compassionate release, ${ }^{429}$ prohibiting any focus on the age of the offender seems unlikely and ill-advised. Instead, the wiser solution is the more difficult task of educating the federal judiciary about sentencing disparities involving doctors and other white-collar offenders.

\footnotetext{
427 See Stephen J. Schulhofer, Excessive Uniformity - And How to Fix It, 5 FED. SENT'G REP. 169, 170-71 (1992).

428 See, e.g., U.S. Sentencing Comm'n, U.S. Sentencing Guidelines Manual $\S 5 \mathrm{H} 1.10$ (2018) (stating that race, sex, national origin, creed, religion, and socioeconomic status are "not relevant in the determination of a sentence").

429 See 34 U.S.C. § $60541(\mathrm{~g})(1)(\mathrm{A})$ (2018).
} 